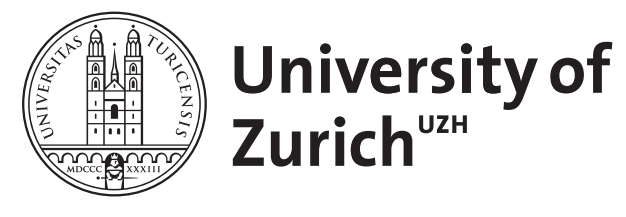

\title{
Renal handling of phosphate and sulfate
}

\author{
Biber, J ; Murer, H ; Mohebbi, N ; Wagner, C A
}

\begin{abstract}
In the kidney, both anions, phosphate and sulfate, are almost freely filtered and afterwards reclaimed (reabsorbed) to a large extent from tubular fluid along the proximal tubules. Under normal dietary conditions, fractional excretion of these anions is approximately $10 \%$. Reabsorption of both anions occurs along the proximal tubules by active, saturable, and regulated transepithelial processes. Most of the transporters involved in renal handling of phosphate and sulfate have been identified and their transport functions as well as their cellular localizations have been described in detail. The role of these transporters in the renal handling of phosphate and sulfate has been investigated by the use of several mice knock out models and also by analysis of several inherited human diseases. Numerous hormonal and nonhormonal factors, have been described that alter renal excretion of phosphate or sulfate by mechanisms that alter the abundance of known phosphate/sulfate transporters and consequently renal excretion. These mechanisms contribute to the homeostasis of the extracellular concentrations of phosphate and sulfate. (C) 2014 American Physiological Society. Compr Physiol 4:771-792, 2014.
\end{abstract}

DOI: https://doi.org/10.1002/cphy.c120031

Posted at the Zurich Open Repository and Archive, University of Zurich ZORA URL: https://doi.org/10.5167/uzh-95625

Journal Article

Accepted Version

Originally published at:

Biber, J; Murer, H; Mohebbi, N; Wagner, C A (2014). Renal handling of phosphate and sulfate. Comprehensive Physiology, 4(2):771-792.

DOI: https://doi.org/10.1002/cphy.c120031 


\title{
Renal handling of phosphate and sulfate
}

\author{
J. Biber, H. Murer, N. Mohebbi, C.A. Wagner
}

\section{ABSTRACT}

In the kidney, both anions, phosphate and sulfate are almost freely filtered and afterwards reclaimed (reabsorbed) to a large extent from tubular fluid along the proximal tubules. Under normal dietary conditions, fractional excretion of these anions is approximately $10 \%$. Reabsorption of both anions occurs along the proximal tubules by active, saturable and regulated transepithelial processes. Most of the transporters involved in renal handling of phosphate and sulfate have been identified and their transport functions as well as their cellular localizations have been described in detail. The role of these transporters in the renal handling of phosphate and sulfate has been investigated by the use of several mice knock out models and also by analysis of several inherited human diseases. Numerous hormonal and non hormonal factors, have been described that alter renal excretion of phosphate or sulfate by mechanisms that alter the abundance of known phosphate/sulfate transporters and and consequently renal excretion. These mechanisms contribute to the homeostasis of the extracellular concentrations of phosphate and sulfate.

\section{PHOSPHATE}

Inorganic phosphate is a nutrient that is essential for many biological processes, such as bioenergetics, metabolic regulation, and for structures such as bones and membranes. In addition, phosphate participates in acidbase balance by contributing to urinary buffering. Approximately $85 \%$ of total phosphate is located in bone and teeth, $14 \%$ resides in soft tissues and erythrocytes and only $1 \%$ circulates as free phosphate in extracellular fluids.

Dietary intake of phosphate is closely related to the intake of meats, vegetables, and dairy products. As general estimates, milk and milk products contain $\sim 250$ to $300 \mathrm{mg}$ of phosphorus per typical serving; meat and fish $\sim 100$ -200 mg; vegetables, $50-100 \mathrm{mg}$; and fruits and grain products, 10-50 mg. 
The recommended daily dietary allowance for phosphorus is around $800 \mathrm{mg}$ for adults and $1200 \mathrm{mg}$ for children between ages of 11 and 18 years (see http://pi.oregonstate.edu/infocenter/minerals/phosphorus). A minimum daily requirement is uncertain because negative balance is difficult to achieve in healthy persons. In the absence of abnormalities that affect the gastrointestinal or renal handling of phosphate and/or bone metabolism, the overall output of phosphate adjusts to the intake over a wide range (228).

Organic phosphates ingested in foods are hydrolyzed in the gastrointestinal tract to form inorganic phosphate. Phosphate absorption along the gastrointestinal tract appears to involve two components: i) a transcellular absorptive component, that involves type II and type III Na/Pi-cotransporters $(108,206,251)$ and ii) a concentration- or load- dependent absorptive component that may represent paracellular diffusion, that, however, is poorly characterized. The sum of these processes results in an overall fractional absorption of phosphate that ranges between $65 \%$ and $70 \%$ of the amount ingested (229). Notably, segmental distribution of absorption of phosphate varies among different species. In humans and rats most of the ingested phosphate is absorbed in the upper intestinal segments duodenum and jejunum, whereas in mice, most of the phosphate absorption occurs in the ileum $(206,207,244)$. The role of the colon is uncertain.

Overall, control of the extracellular concentration of phosphate depends to a large extent on mechanisms that govern renal excretion of phosphate. Renal excretion of phosphate, and to a lesser extent gastrointestinal absorption of phosphate, is controlled by complex regulatory networks that involve several organs and several endocrine factors $(31,91,169,206,208,279)$.

\section{PLASMA PHOSPHATE CONCENTRATION}

In plasma, phosphate exists in both the monovalent and the divalent form. Based on the pK-value of 6.8 , at blood $\mathrm{pH}$ of $7.4,72 \%$ of plasma phosphate is present in the divalent $\left(\mathrm{HPO}_{4}{ }^{ }\right)$and $28 \%$ is present in the monovalent $\left(\mathrm{H}_{2} \mathrm{PO}_{4}^{-}\right)$form. In adult humans, total steady-state phosphate concentration in the plasma ranges between 0.8 and $1.2 \mathrm{mM}$ ( 2.5 to $3.75 \mathrm{mg}$ per deciliter). Different species maintain different normal values for plasma phosphate 
concentrations (164). These differences have been correlated with basal metabolic rates. High plasma levels of phosphate occur in mammalian species that exhibit high rates of oxygen consumption and ATP production (267). Plasma phosphate concentrations exhibit diurnal fluctuation due to mechanisms that are not fully understood. In individuals on normal diets, several studies showed consistently that serum concentration of phosphate is highest after midnight and lowest around between morning and midday (205, 238). These diurnal variations are closely matched by a diurnal variation of renal phosphate excretion (37).

Deviations from normal serum phosphate concentrations cause severe clinical disorders. Even slight elevations have been associated with increased rates of death due to cardiovascular complications (292) that are common among patients with chronic kidney disease (136). On the other hand, prolonged hypophosphatemia, caused by e.g. malabsorption or inherited disorders such as X-linked hypophosphatemia (287), results in a number of symptoms such as osteomalacia, hypercalciuria and bone demineralization $(7,153)$.

\section{METABOLIC REQUIREMENT FOR PHOSPHATE}

Inorganic phosphate serves as a cofactor in pathways of energy metabolism such as glycolysis and oxidative phosphorylation. Additionally, phosphate is a cofactor for enzymatic activities involved in a number of metabolic pathways, such as ammoniagenesis or glycogenolysis, and intracellular signaling pathways $(36,42,43)$. Moreover, phosphate is required for DNA synthesis and cell replication. Values for intracellular inorganic phosphate concentration/activity are difficult to determine because of the high content and rapid turnover of various organic phosphates. By ${ }^{31} \mathrm{P}-\mathrm{NMR}$, intracellular concentration of phosphate has been estimated to be around $0.7 \mathrm{mM}$. This value is approximately $30 \%$ of values determined chemically (100).

When isolated proximal convoluted tubules are luminally perfused with phosphate-free solution, net sodium transport is eliminated and only partially restored by subsequent perfusion with phosphate-containing fluid. These changes occur inspite of $2 \mathrm{mM}$ phosphate in the bathing medium. Of interest, inhibition of D-glucose transport protects tubular function from limited 
phosphate availability (41). These studies indicate that the uptake of luminal phosphate represents a major source for intracellular organic and inorganic phosphates and additionally, that glucose metabolism and mitochondrial respiration compete for a limited pool of available phosphate $(41,42)$. Similar phenomena have been described in other tissues as "the Crabtree effect". Limited phosphate availability could impair mitochondrial uptake of substrates whose transport is coupled directly or indirectly to phosphate. Support for this possibility derives from observations that mitochondrial substrates such as succinate, malate, citrate, and glutamate partially restore the transport function of phosphate-limited tubules (117). Alternatively, limited phosphate availability may impair the mitochondrial uptake of calcium or the maintenance of the mitochondrial potential.

\section{RENAL HANDLING OF PHOSPHATE}

The overall renal handling of phosphate involves glomerular filtration and tubular reabsorption. There is no evidence for significant secretion of phosphate in kidneys of mammals (115). Phosphate reabsorption displays saturability, but maximal rates vary considerably in response to phosphate intake and levels of different phosphaturic factors. The tubular transport maximum $(\mathrm{Tm})$ for phosphate, therefore, is a variable rather than a constant parameter. As Tm varies with the glomerular filtration rate (GFR), the renal threshold for phosphate (Tm/GFR) should be preferred as a description of the overall renal handling of phosphate. Its normal range lies between 0.77 to 1.4 $\mathrm{mMol} / \mathrm{L}$ (317). In response to extremes of phosphate intake, the kidneys may excrete close to $100 \%$ of the filtered load or as little as none. For individuals in phosphate balance, the daily urinary excretion of phosphate equals the net amount absorbed from the intestinal tract and usually represents $10-20 \%$ of the amount filtered (fractional excretion).

The phosphate concentration in the glomerular ultrafiltrate is determined by the plasma phosphate concentration and the Donnan equilibrium distribution. Measured values of concentrations of phosphate in the ultrafiltrate range between $92 \%$ and $98 \%$ of the concentration in plasma water or about $90 \%$ of that in total plasma (175). Ultrafilterability declines with increases in plasma calcium concentration in the range between $2.6 \mathrm{mM}$ and $4.6 \mathrm{mM}$. At very high 
plasma calcium concentration ultrafilterability may decrease to about $78 \%$ (126).

\section{Localization of Renal Phosphate Reabsorption}

Under normal conditions, phosphate reabsorption occurs mainly and essentially only in the proximal tubules. Using free-flow micropuncture techniques, it was observed that the accessible portion of the proximal tubule reabsorbed $76 \%$ of the phosphate that was filtered (278). The fraction of filtered phosphate remaining at the end of the proximal tubule (24\%) was not different from values measured at the early distal tubule or in the urine indicating that there was no evidence for any net transport of phosphate distal to the accessible proximal tubule when the parathyroid glands were intact. On the other hand, other studies provided evidence for a possible, distal tubular reabsorption of phosphate of approximately 5 to $10 \%$ of the filtered phosphate (9). Molecular mechanisms eventually involved in distal tubular reabsorption of phosphate are, however, completely unknown.

Phosphate transport in the proximal tubule displays both axial and internephronal heterogeneity. The latter refers to differences among different populations of nephrons such as superficial versus juxtamedullary. Microperfusion studies of individual proximal tubules demonstrated that phosphate transport rates per unit length did not differ between segments derived from superficial versus juxtameduallary nephrons (210). Therefore, internephron heterogeneity may arise from differences in the lengths or axial composition of superficial and juxtamedullary nephrons. With regard to axial heterogeneity, phosphate reabsorption in the earliest portion, the proximal convoluted tubule (S1), is estimated to be 3 to 4 times higher per unit length compared to the convoluted S2 portion $(210,303)$. In the proximal straight tubule (S3), rates of phosphate reabsorption are even lower (82). In agreement, higher phosphate transport rates have been demonstrated in brush border membrane vesicles isolated from superficial cortex compared to vesicles isolated from juxtamedullary cortex (180). 


\section{CELLULAR MECHANISMS OF PHOSPHATE TRANSPORT}

Phosphate reabsorption in the proximal tubule is fundamentally an unidirectional, transcellular process that is strictly dependent on the presence of sodium-ions. A small component of bath-to-lumen flux was reported that may occur via a paracellular pathway. If existing at all, this pathway is not affected by factors that inhibit or enhance phosphate movement from lumen to bath $(83,224,271)$.

Phosphate transport across the luminal, apical membrane occurs via sodiumdependent secondary active transport processes that are driven by active extrusion of sodium-ions at the basolateral surface mediated by $\mathrm{Na} / \mathrm{K}$ ATPase. Basolaterally located exit transport mechanisms complete transcellular movement of phosphate.

\section{Phosphate Entry}

At the apical side of proximal tubular cells phosphate uptake occurs against its own electrochemical gradient. At a negative membrane potential of approximately $-60 \mathrm{mV}$, the free intracellular concentration of phosphate at equilibrium should be roughly 10-times lower than in the extracellular space. However, several measurements indicated that the intracellular concentration of phosphate is around $1 \mathrm{mM}$ and therefore far above the predicted low intracellular concentration of phosphate (100). This suggests that the apical entry of phosphate must be energized. In fact energization is achieved by coupling with sodium-flux that occurs by secondary active sodium-dependent phosphate cotransporters.

Strict dependency of phosphate transport across the apical membrane in proximal tubules on the presence of sodium-ions has been demonstrated in several in vivo (tubules) and in vitro (cells, tubules, purified membranes) assays $(83,296)$. The major action of sodium-ions is to activate the binding of phosphate to the transport site (312). Sodium dependent transport of phosphate ( $\mathrm{Na} / \mathrm{Pi}$-cotransport) has been extensively characterized by the use of proximal tubular brush border membrane vesicles isolated from kidneys of different species $(83,224,296)$ and by electrophysiological methods using oocytes from Xenopus laevis expressing single $\mathrm{Na} / \mathrm{Pi}$-cotransporters (98, 99, 312). Sodium dependence and other characteristics (e.g. pH dependence) of 
apical entry of phosphate can be fully explained by the characteristics of cloned $\mathrm{Na} / \mathrm{Pi}$-cotransporters.

\section{$\mathrm{Na} / \mathrm{Pi}$-cotransporters}

Physiologically relevant $\mathrm{Na} / \mathrm{Pi}$-cotransporters identified thus far and localized at the apical membrane of proximal tubules belong to the solute carrier families SLC20 and SLC34 (see www.bioparadigms.org/slc/intro.htm) (Figure 1). Some members of the SLC17 family were reported to exhibit $\mathrm{Na} / \mathrm{Pi}$ cotransport activity in heterologous expression systems as well, however, it appears unlikely that these transporters play a role in renal handling of phosphate. SLC17a1 (NaPi1) has been cloned based on its (weak) Na/Picotransport activity (324) and has been localized at the brush border membrane of proximal tubules (64). Its role in renal phosphate handling is rather unlikely as neither PTH nor dietary phosphate regulate $\mathrm{NaPi1}$ protein abundance (224). Furthermore, after expression in oocytes of Xenopus laevis, detailed analysis suggested that $\mathrm{NaPi1}$ is transporting various organic anions $(47,246)$. Moreover, as demonstrated with purified and reconstituted NaPi1 protein, NaPi1 may act as a voltage and chloride dependent urate exporter in proximal tubules (135). As a single nucleotide polymorphism in SLC17A1 has been associated with gout (80), thus urate transport by NaPi1 could be of particular importance in the development of this disease. Another member of the SLC17 family, SLC17A3, was also shown to be localized at the brush border of proximal tubules (139). After expression of SLC17A3 in Xenopus oocytes, transport of phosphate could be demonstrated that was dependent on the presence of sodium-ions. However, the role of SLC17A3 in renal handling of phosphate is not clear. Rather, SLC17a3 appears to be an anion efflux transporter for urate and loop diuretics (145).

The two members of the SCL20 family [SLC20a1 (PiT1) \& SLC20a2 (PiT2)] were originally identified as retroviral receptors and later on demonstrated to exhibit $\mathrm{Na} / \mathrm{Pi}$-cotransport activity $(61,148)$. In kidney, PiT2 was localized at the brush border membrane in proximal tubules (309). In rat kidney PiT2 was detected in S1 and to a lesser degree in S2 segments (236). The localization of the PiT1 protein remains to be determined. Na/Pi-cotransport by PiT proteins is electrogenic due to a stochiometry of $2 \mathrm{Na}^{+}$to $1 \mathrm{HPO}_{4}^{-}(98,245)$. 
PiT transporters do not transport sulfate, but interaction with arsenate has been demonstrated $(245,312)$. The role of PiT2 in proximal tubular reabsorption of phosphate under normal physiological conditions was suggested to be marginal (310). Na/Pi-cotransport activity of PiT transporters is higher at more acidic pH-values $(245,310)$, therefore PiT mediated phosphate reabsorption may be of primary importance under pathological conditions (e.g. acidotic conditions). The precise role of PiT2 in overall renal handling of phosphate and its regulation remains to be determined.

Both, NaPi-Ila (SLC34A1) and NaPi-Ilc (SLC34A3) have been localized at the luminal membrane of proximal tubules $(98,224,236,315)$. Abundance of $\mathrm{NaPi}-\mathrm{lla}$ is highest in S1 segments and decreases towards S3 segments. $\mathrm{NaPi}$-llc has been localized only in the S1 segment (236). Transport kinetics of both isoforms have been extensively studied after heterologous expression in oocytes of Xenopus laevis $(98,99)$. A fundamental difference between NaPiIla and $\mathrm{NaPi}-\|_{\mathrm{l}}$ lies in the coupling to $\mathrm{Na}^{+}$-ions. Whereas $3 \mathrm{Na}^{+}$ions are transported together with one divalent phosphate ion $\left(\mathrm{HPO}_{4}{ }^{2-}\right)$ by $\mathrm{NaPi}-\mathrm{lla}$, only $2 \mathrm{Na}^{+}$-ions are transported with one $\mathrm{HPO}_{4}{ }^{2-}$-ion by $\mathrm{NaPi}$-llc. Thus, $\mathrm{Na} / \mathrm{Pi}$ cotransport by $\mathrm{NaPi}$-lla is an electrogenic process, whereas $\mathrm{Na} / \mathrm{Pi}$-cotransport by $\mathrm{NaPi}-I_{\mathrm{C}}$ is an electroneutral process. Both cotransporters show similar $\mathrm{pH}$ dependence with higher rates at more alkaline $\mathrm{pH}$-values (315).

The roles of NaPi-lla and NaPi-llc cotransporters in proximal reabsorption of phosphate can be deduced from several observations made with different knock out mouse models and from observations made with several genetic diseases in humans (216). In mice, the important role of NaPi-lla has been documented by knocking out the Npt2 gene $(19,288)$. These mice are hypophosphatemic due to phosphate wasting that can be explained by an approximately $70 \%$ reduced $\mathrm{Na} / \mathrm{Pi}$-cotransport rate in isolated brush border membranes. In humans, the role of $\mathrm{NaPi}$-lla has been documented less well. Although genetic variants within the NPT2a gene are often observed, these polymorphisms could not be conclusively linked to renal phosphate anomalies (165). On the other hand, an in-frame duplication of a stretch of seven amino acids has been reported in two siblings of a family with hypophosphatemic rickets (190). Renal wasting of phosphate in these patients is associated with Fanconi's syndrome, suggesting that either the duplication of the described 
amino acid motif in NaPi-lla proteins may also affect other proximal tubular transporters as well, e.g. by interfering with sorting or that the genetic defect lies in another gene not identified yet.

In contrast to NaPi-lla, ablation of the NaPi-llc cotransporter did not impair homeostasis of phosphate nor was renal reabsorption of phosphate affected in adult mice (264). These observations suggested that, in adult mice, NaPi-llc plays a minor role in overall renal handling of phosphate. However, opposite to mice, in patients with hereditary hypophosphatemic rickets with hypercalciuria (HHRH, OMIM \#241530) mutations within the NaPi-llc gene have been described that explain the renal wasting of phosphate in these patients $(7,28,185,240)$. Altogether, current findings suggest that NaPi-lla and $\mathrm{NaPi}$-llc $\mathrm{Na} / \mathrm{Pi}$-cotransporters represent the major players in renal handling of phosphate but may contribute differently in different species.

\section{Phosphate Exit}

The molecular identity of phosphate transport across the basolateral membrane is currently not known. Based on basolateral membrane preparations, several transport mechanisms have been proposed. However, because purified basolateral membrane fractions are relatively undefined, it has remained difficult to demonstrate that the transport phenomenon does not represent contamination from other membranes, especially mitochondrial or brush border material.

Uptake of phosphate into basolateral membrane vesicles from dog kidney demonstrated features different from uptake in brush border membrane vesicles. Although sodium-dependency has been demonstrated, uptake into basolateral membrane preparations lacked pH-sensitivity (261). Even if present in basolateral membranes in vivo, an electrogenic, sodium gradientdependent transport mechanism would favour a basolateral entry - rather than exit- of phosphate, and thus such a mechanism is difficult to integrate into models of net transcellular transport of phosphate. However, it has been proposed that such a mechanism could be involved in protecting the proximal tubule from limited availability of intraluminal phosphate (262).

Other investigations suggested an anion-exchange mechanism based on the observation that preloading basolateral vesicles with phosphate stimulated 
phosphate uptake in the absence of sodium $(119,187)$. For an anionexchange mechanism to achieve net exit of phosphate, some other counterion must be exchanged. The identity of such a counter-ion is not known. Experimental evidence was provided that the phosphate exchange mechanism is distinct from the basolateral sulfate exchange mechanism (116, $119,188)$.

\section{REGULATION OF PHOSPHATE EXCRETION}

Excretion of phosphate is tightly controlled and adjusted to the metabolic needs by a long list of hormones and metabolic factors which primarily affect the abundance of $\mathrm{Na} / \mathrm{Pi}$-cotransporters residing in proximal tubular brush border membranes and therefore net rate of reabsorption of phosphate. These factors are integrated into complex regulatory networks that acutely and chronically regulate renal phosphate reabsorption. These networks comprise different organs such as bone, small intestine, and parathyroid glands $(6,31,34,83,160,208,279)$.

\section{Parathyroid Hormone}

Parathyroid hormone (PTH) primarily regulates calcium homeostasis but in addition regulates serum phosphate levels by controlling proximal tubular phosphate reabsorption (107). Acute administration of PTH causes an increase of phosphate excretion within minutes that lasts for several hours $(35,98)$. PTH has the potential to reduce phosphate transport along the entire proximal tubule. The action of PTH in different proximal tubular segments may be influenced by excessive or restricted dietary phosphate availability (112). In addition, PTH also inhibits proximal reabsorption of sodium and bicarbonate by inhibition of the amiloride sensitive sodium-proton exchanger NHE3 (5) and stimulates production of 1, 25-dihydroxyvitamin $D_{3}$ (88).

In proximal tubules, PTH exerts its effect via the PTH receptor PTHR1, which is localized at the basolateral as well as at the luminal membrane. Apical PTHR1 is coupled to $\mathrm{Gq}$ and activates a $\mathrm{PLC} / \mathrm{IP}_{3} / \mathrm{Ca}^{2+} \mathrm{PKC}$ pathway, while basolateral PTHR1 is coupled to Gsa and activates a cAMP/PKA pathway (293). Activation of both PTHR1 pools results in increased excretion of 
phosphate due to a decrease of the abundance of apical $\mathrm{Na} / \mathrm{Pi}$ cotransporters. In-vivo studies using different PTH analogs demonstrated that down-regulation of the $\mathrm{Na} / \mathrm{Pi}$-cotransporter $\mathrm{NaPI}-$ lla (see below) occurs primarily via the CAMP/PKA pathway (225)

PTH provokes a decrease of $\mathrm{Na} / \mathrm{Pi}$-cotransporters $\mathrm{NaPi}-$ Ila and $\mathrm{NaPi}-\mathrm{llc}$, yet by different mechanisms and time courses $(209,236,265,266)$. After intravenous injection of PTH, a decrease of apical abundance of NaPi-lla proteins is detectable after $15 \mathrm{~min}$ and persists for several hours, while a decrease of the abundance of NaPi-llc proteins was detected only after more than two hours. Also the abundance and activity of PiT2 is regulated by PTH but the mechanism may be different since no internalization of PiT2 transporters could be detected by immunohistochemistry (236).

Within minutes, PTH leads to an internalization of NaPi-lla that occurs at the intermicrovillar clefts via clathrin coated vesicles. There is no evidence for a recycling of internalized $\mathrm{NaPi}$-lla proteins; neither there is evidence for a intracellular pool from which NaPi-lla proteins could be recruited. After endocytosis, NaPi-lla proteins colocalize with early endosomes from where they are sorted and trafficked to lysosomes and degraded $(98,151,236)$. In contrast, NaPi-Ilc proteins have not been detected in a lysosomal fraction after PTH treatment, although the abundance in the brush border membrane was decreased with a delay of several hours (265). The exact mechanism involved in the down-regulation of the amount of NaPi-llc proteins by PTH remains to be determined.

$\mathrm{NaPi}-l l a$ was demonstrated to interact with several proteins. Among those, the PDZ domain containing proteins NHERF1 (sodium-proton exchanger regulatory factor 1) and NHERF3 (PDZK1) showed most robust interactions in in-vitro assays $(110,129)$. These interactions occur via the most $\mathrm{C}$-terminal amino acids (TRL) of NaPi-lla. NHERF1 contains two PDZ domains, of which the first one interacts with NaPi-lla $(110,129)$ and a MERM (merlin-ezrinradixin-moesin) binding domain that, via ezrin, links NHERF1 to the $\beta$-actin cytoskeleton. As demonstrated with NHERF1 knock out mice, NHERF1 is instrumental for stabilizing NaPi-lla proteins at the apical membrane $(63,268)$. In these mice, the apical abundance of $\mathrm{NaPi}$-lla proteins was reduced resulting in increased urinary phosphate excretion. Reduced abundance of 
$\mathrm{NaPi}$-lla proteins at the apical membrane was associated with accumulation in intracellular structures indicating an impaired targeting of $\mathrm{NaPi}$-lla proteins to the apical membrane. Furthermore, NHERF1 plays an important role in PTH stimulated endocytosis of $\mathrm{NaPi}$-lla. The affinity of NHERF1/NaPi-lla interaction is decreased by phosphorylation of a serine residue (ser77) that is located within the first PDZ domain of NHERF1 by either signalling cascade (PKA, PKC) activated by PTH (322). Consequently, increased mobility of NaPi-lla allocates NaPi-lla for endocytosis (323).

In addition to NaPi-lla, NHERF1 also interacts with PTH receptor PTHR1 and phospholipase C (191). In agreement, apical PTH signaling, but not basolateral signaling was shown to be impaired in NHERF1 deficient mice (49).

In addition to NHERF1, NaPi-lla strongly interacts with the four PDZ domain containing protein NHERF3 (PDZK1, Cap1) (129) that has been localized at the proximal tubular brush borders as well. However, PDZK $^{--}$mice, exhibit a mild phosphaturic phenotype only under high phosphate diets (50). Besides $\mathrm{NaPi}-I l a, \mathrm{NaPi}-$ Ilc was shown to interact with NHERF3 (PDZK1) as well (308). Functional significance of this interaction was observed in PDZK $1^{-1-}$ mice fed chronically with low phosphate diet. Compared to wild type mice, upregulation of $\mathrm{NaPi}-\mathrm{Ilc}$ in $\mathrm{PDZK} 1^{-1-}$ was impaired while up-regulation of $\mathrm{NaPi}$-lla was normal (109). These studies suggest that NHERF3 is involved in the slow adaptive response of $\mathrm{NaPi}-I_{\mathrm{lc}}$ to low phosphate diet and does not play a role in the fast adaptive response of $\mathrm{NaPi}-l l a$.

Moreover, the epithelial form of shank2 has been shown to interact with NaPi$\mathrm{Ila}$ as well. Microscopic analysis provided evidence that apically localized shank2 cotrafficks together with NaPi-lla under conditions that lead to a downregulation of $\mathrm{NaPi}$-lla proteins, such as during acutely given high phosphate diet (86).

\section{Phosphatonins/Klotho}

In recent years, several new phosphaturic factors, now collectively named as phosphatonins, have been identified that contribute to the maintenance of phosphate homeostasis. Originally, the term phosphatonin has been coined to describe circulating phosphaturic factors that are elevated in several diseases, 
such as oncogenic osteomalacia (OOM), autosomal dominant hypophosphatemic rickets (ADHR), and X-linked hypophosphatemic rickets (XLHR) $(31,160)$. These diseases are characterized by hyperphosphaturia, hypophosphatemia, and inappropriately normal or low levels of 1,25dihydroxyvitamin $D_{3}$. To date, the following phosphatonins have been identified: fibroblast growth factor 23 (FGF23), secreted frizzled related protein 4 (sFRP4) and matrix extracellular phosphoprotein (MEPE) (2, 31, 325). The attribution of fibroblast growth factor 7 (FGF-7) is controversial since no phosphaturic effects in vivo could be detected.

FGF23, is primarily produced and secreted by osteocytes and osteoblasts (92). Small levels of mRNA were detected in other tissues such as liver, parathyroid glands, and small intestine (2). The uncleaved, biologically active form of FGF23, consists of 215 amino acids. Cleavage and inactivation of FGF23 occurs at a subtilisin-like proprotein convertase site at position 176 (R176XXR). Mutations at these positions have been associated with ADHR due to reduced cleavage and consequently increased levels of FGF23 (13, 270). Proteolytic cleavage may also be influenced by altered O-glycosylation of FGF23 by UDP-N-acetyl- $\alpha$-D-glactosamine: polypeptide $\mathrm{N}$-acetylglactosaminyltransferase (GALNT3) that has been associated with familial tumoral calcinosis (274).

FGF23 has emerged as the possibly most important regulator of phosphate homeostasis, although, compared to PTH secretion, changes of serum concentrations of FGF23 occur more slowly. Synthesis and secretion of FGF23 is stimulated by dietary phosphate $(46,95,231,235$,$) and 1,25-$ dihydroxyvitamin $D_{3}$ (154). As a feedback mechanism, FGF23 inhibits the production of $1,25(\mathrm{OH})_{2}$ vitamin $\mathrm{D}_{3}$ via inhibition of $1 \alpha$-hydroxylase activity and increase of 24-hydroxylase activity (183). FGF23 also suppresses synthesis and release of PTH from parathyroid glands (272).

Several in-vivo and in-vitro investigations documented that the phosphaturic effect of FGF23 can be explained by alterations of the apical abundances of proximal tubular $\mathrm{Na} / \mathrm{Pi}$-cotransporters. Phosphaturia in FGF23 transgenic 
mice correlates with reduced amounts of both NaPi-lla and NaPi-Ilc (166) and overexpression of FGF23 and in-vitro treatment of isolated proximal tubules affected abundances of proximal tubular apical $\mathrm{Na} / \mathrm{Pi}$-cotransporters $\mathrm{NaPi}-\mathrm{lla}$, NaPi-llc and PiT2 (17, 258, 291). FGF23 null mice exhibit severe hyperphosphatemia and have elevated serum levels of 1,25-dihydroxyvitamin $D_{3}(269)$.

The phosphaturic effect of FGF23 is mediated via the canonical FGF receptor FGFR1c and requires the membranous form of Klotho as cofactor $(106,306)$. Cellular signaling elicited by this receptor complex was described to occur via the MAPK kinase pathway $(90,91,326)$. The exact signaling cascade regulating $\mathrm{Na} / \mathrm{Pi}$-cotransporters by FGF23 remains to be determined. In kidney, Klotho is expressed mainly in distal tubules (90). Injection of FGF23 was shown to induce phosphorylation of MAPK in distal tubules in parallel to a reduction of $\mathrm{NaPi}$-lla protein in proximal tubules, indicating that an unknown paracrine mechanism could be involved in the action of FGF23 on proximal tubular $\mathrm{Na} / \mathrm{Pi}$-cotransporters (90). However, low expression of klotho was demonstrated in proximal tubules as well (134) and therefore may suggest that klotho acts also in an autocrine manner in proximal tubules.

Klotho protein is composed of two extracellular domains that show similarity to $\beta$-glycosidases, thus, alternatively to its FGF receptor cofactor function, Klotho may modify transporter function directly via hydrolysis of sugar residues. Evidence for such action of Klotho has been provided in in-vitro experiments. Incubation of isolated proximal tubular brush border membranes with recombinant Klotho protein leads to an inhibition of $\mathrm{Na} / \mathrm{Pi}$-cotransport (134). Frizzled-related protein 4 is overexpressed in OOM tumors $(30,31)$. sFRP-4 elicits an increase of phosphate excretion that is caused by a decrease of $\mathrm{Na} / \mathrm{Pi}$-cotransporter NaPi-lla abundance $(29,30)$. sFRP-4 was shown to alter phosphorylation of beta-catenin pointing to a mechanism involving the Wntsignalling pathway up-stream to a down-regulation of $\mathrm{NaPi}-l l a(29)$.

MEPE and FGF7 were identified from tumor tissues of patients exhibiting renal phosphate wasting (31). MEPE, a member of the SIBLING (short integrin-binding ligand interacting glycoprotein) protein family, is primarily expressed in bone cells. The phosphaturic action of MEPE is paralled by a decrease of apical NaPi-lla protein abundance (85). In cell culture studies, 
FGF7 inhibits $\mathrm{Na} / \mathrm{Pi}$-cotransport (53). Cellular mechanisms involved in the phosphaturic action of MEPE and possibly FGF7 are not known.

\section{Catecholamines}

Nerve endings in proximity to renal tubules release norepinephrine, which acts on proximal tubule to increase sodium, phosphate, and bicarbonate reabsorption (18). These effects are explained by a stimulatory action of norepinephrine on the sodium/potassium pump, as evidenced by norepinephrine induced increases in transport related oxygen consumption and ATP hydrolysis. The effect of epinephrine on renal phosphate handling may be indirect via stimulation of PTH secretion (96).

In kidney, dopamine is synthesized primarily in proximal tubules (274 and its production is regulated by dietary intake of phosphate via stimulation of DOPA decarboxylase activity (321). A number of studies showed that dopamine is both natriuretic and phosphaturic due to autocrine/paracrine actions (105, 111). The phosphaturic effect of dopamine has been demonstrated in several animal models and cultured renal cells $(78,137,140,167)$. Administration of dopamine or its precursors elicit reduced $\mathrm{Na} / \mathrm{Pi}$-cotransport at the brush border membrane $(84,137)$ that is explained by internalization of $\mathrm{NaPi}$-lla cotranporters (11).

Differential inhibition of D1 and D2 receptors indicated that stimulation of apically localized D1 receptors, via a cAMP/PKA pathway, increase the rate of internalization of NaPi-lla $(11,62)$. Similar as for PTH mediated internalization of NaPi-lla, NHERF1 plays a key role in dopamine induced internalization of $\mathrm{NaPi}-$ lla. The signaling cascade activated by dopamine leads to phosphorylation of Ser77 within a PDZ domain of NHERF1 resulting in a decreased affinity for NaPi-lla (320).

\section{Atrial Natriuretic Peptide/NO}

Atrial natriuretic factors represent a series of peptides that besides vascular actions also have direct effect on proximal tubular functions. Early studies demonstrated that ANP causes phosphaturia associated with a decrease of brush border membrane $\mathrm{Na} / \mathrm{Pi}$-cotransport (330). Nitric oxide (NO) was 
shown to regulate proximal tubular transport by autocrine/paracrine mechanisms (155).

Guanylate cyclase is activated by both ANP and NO (319). In mice and cultured renal cells administration of ANP and NO donors resulted in a decrease of NaPi-lla cotransporters. These effects could be mimicked by pharmacological activation of protein kinase $\mathrm{G}$ by $8 \mathrm{Br}$-cGMP and inhibited by protein kinase $G$ inhibitors. In-vitro perfusion of isolated proximal tubules suggested the presence of ANP receptors at both membrane sites (12). At this time the target for activated PKG is not known.

\section{Growth Hormone}

Growth hormone (directly or indirectly mediated by insulin-like growth factor I) acts on renal proximal tubule to increase phosphate reabsorption $(54,122$, 124). Receptors for IGF likely reside in the basolateral membrane (124). In juvenile rats suppression of growth hormone reduced reabsorption of phosphate and abundance of the NaPi-lla cotransporter to a similar level as observed in adult rats (326). These observations suggest that growth hormone plays an important role in up-regulated phosphate reabsorption in young animals which likely is due to higher anabolic needs.

\section{Insulin/Glucagon}

Insulin infusions coupled with sufficient glucose to maintain euglycemia increase renal reabsorption of phosphate in humans (79). Renal cortical tubules display specific binding of insulin, and insulin added to proximal tubules in vitro increases $\mathrm{Na} / \mathrm{Pi}$-cotransport in brush border membrane vesicles derived from these tubules (123). At this time, no further information about the cellular mechanisms of insulin action are known. A pathway including the serine/threonine kinase mTOR could be envisaged as insulin represents a stimulator of mTOR. Accordingly, it has been shown that rapamycin, an inhibitor of mTOR, resulted in phosphaturia (149). Furthermore, insulin was proposed to have a role in the adaptive response of renal handling to low Pi-diet. In rats with streptozotocin-induced diabetes, no increase of $\mathrm{Na} / \mathrm{Pi}$-cotransport in isolated brush border membranes was detected after low 
Pi-diet given for three days (1). Interestingly, at the whole kidney level the adaptive response was normal.

Glucagon may have direct actions on the kidney to enhance calcium and magnesium reabsorption, probably in the thick ascending limb of Henle, but any effects on phosphate excretion are probably indirect (14).

\section{Glucocorticoids}

Glucocorticoids, like dexamethasone, triamcinolone, and hydrocortisone increase phosphate excretion by inhibition of brush border $\mathrm{Na} / \mathrm{Pi}$-cotransport (184). Independent from the presence of PTH, pharmacologic doses result in decreased phosphate reabsorption within $1-2 \mathrm{~h}$ (103). There is special interest in the relationship between glucocorticoids and phosphate transport because glucocorticoids participate importantly in the renal response to metabolic acidosis, including phosphaturia $(40,102)$ and chronic treatment with glucocorticoids leads to loss of bone mass.

Work performed with cultured renal cells provided evidence for a genomic as well as for a non-genomic mechanism of glucocorticoid-induced phosphate excretion. The latter may be mediated by PKC rather than PKA $(232,313)$.

\section{Calcitonin}

Low doses of calcitonin reduce the fractional excretion of calcium and magnesium but have no effect on phosphate excretion; much higher dosage of calcitonin is required to increase phosphate excretion (52). This suggests that the physiological role of calcitonin is to cause renal conservation of calcium and magnesium, and that increased excretion of phosphate may represent a pharmacological effect. Nevertheless, acute administration of calcitonin increases phosphate excretion. Micropunture studies indicated that calcitonin induced inhibition of phosphate reabsorption occurs in proximal tubules independent of an increase of cAMP (33). Additionally, after a few hours, injection of calcitonin provoked decreased $\mathrm{Na} / \mathrm{Pi}$-cotransport in rat renal brush border membranes (329). Curiously, calcitonin has no demonstrable effect on adenylate cyclase activity in the proximal tubule (55). 


\section{Thyroid Hormone}

Excess thyroid hormone is associated with hyperphosphatemia and increased renal reabsorption of phosphate that is due to altered $\mathrm{Na} / \mathrm{Pi}$-cotransport (328). In addition, thyroxine stimulates $\mathrm{Na} / \mathrm{K}$-ATPase activity providing increased driving force for $\mathrm{Na} / \mathrm{Pi}$-cotransport. Vice versa, the absence of thyroid hormones results in a decrease of of NaPi-lla protein abundance $(4,259)$ and increased renal loss of phosphate (217).

\section{Estrogen}

Estrogen replacement therapy during menopause results in decreased plasma levels of $\mathrm{Pi}$ that has been associated with inhibition of renal phosphate reabsorption $(276,295)$. In a study using ovarectomized rats, inhibition of $\mathrm{Na} / \mathrm{Pi}$-cotransport was observed after treatment with $\beta$-estradiol compared to untreated rats (23). Inhibition of proximal tubular transport of phosphate by estrogen has been associated with a specific decrease of both NaPi-lla mRNA and protein (89) whereas abundance of NaPi-llc was not altered. Furthermore, no changes of Klotho and NHERF1 mRNA contents have been detected. Although estrogen receptors are expressed in proximal tubules (68), a blocker of the $\alpha$ - receptor did not prevent down-regulation of $\mathrm{NaPi}$-lla; a possible involvement of the $\beta$-receptor has not been investigated. Also, it remains to be tested if down-regulation of $\mathrm{NaPi}$-lla is directly mediated by estrogen or indirectly, e.g. by a stimulation of the production of dopamine.

\section{Stanniocalcins}

The polypeptide hormone stanniocalcin 1 (STE1) and the related STE2 are suggested to be involved in the homeostasis of calcium and phosphate (314). Human stanniocalcin 1 reduced phosphate excretion in rats due to a stimulation of brush border $\mathrm{Na} / \mathrm{Pi}$-cotransport $(314,316)$. No direct effect of STE2 in vivo has been examined. In cell culture, a long term inhibitory effect of STE2 on $\mathrm{Na} / \mathrm{Pi}$-cotransport was observed that is likely due to an inhibition of the NaPi-lla promoter activity (138).

STE1 and STE2 are expressed in several tissues (138). In kidney, expression of STE1 has been repeatedly shown in distal tubular segments, whereas proximal tubular expression of STE1 remains controversial. Available data 
therefore suggest that STE1 may act as a paracrine modulator of renal phosphate handling. Renal localization of STE2 is not known (138). Interestingly, expression of STE1 and STE2 mRNA is stimulated by 1,25dihydroxy-vitamin 3 and STE2 mRNA is acutely decreased by PTH $(132,281)$.

\section{Calcium/Magnesium}

It is not possible to provide simple answers to questions about the effects of calcium on phosphate excretion (271). When considering individual studies, one should question the following features: i) Is PTH present or absent? Or, can the observed effects of calcium on phosphate excretion be correlated with corresponding changes in PTH concentrations? ii) Are changes in calcium developing acutely (intravenously over minutes or hours) or chronically (over more than 24 hours)? iii) What are the other specific details regarding changes in calcium concentrations? For instance, are calcium values increased from low to normal, or normal to high, in vivo or in vitro?

Direct tubular effects of calcium on phosphate transport have been studied by various approaches. In isolated tubules from rabbit, increasing the calcium concentration in both bath and the lumen caused progressive increases in phosphate absorption without affecting net sodium transport (250). In vivo microperfusion studies in parathyroidectomized rats demonstrated a decrease in proximal phosphate transport when calcium was omitted from the peritubular and intraluminal fluids, yet changes from 1.5 to $3 \mathrm{mM}$ had no effect (304).

In normal rats fed high magnesium diet, reabsorption of phosphate was increased due to increased abundances of NaPi-lla and NaPi-llc (290). This effect has been correlated with a decrease of PTH concentration. Parathyroidectomy abolished the effects of high magnesium diets on NaPi-Ila whereas the effect on NaPi-llc was not affected, suggesting a PTH independent effect of high Magnesium diet on NaPi-llc.

\section{Hypokalemia/Potassium Deficiency}

Besides impairment of systemic functions, hypokalemia/potassium deficiency provokes morphological changes and affects a number of renal functions including transport rates and metabolic processes. Hypokalemia/ potassium 
deficiency leads to hypophosphatemia due to an increase of urinary phosphate excretion $(141,142,263)$ that was associated with decreased phosphate transport in isolated proximal tubular brush border membranes (45, 331). Of interest, abundances of $\mathrm{Na} / \mathrm{Pi}$-cotransporters are differentially affected by potassium deficiency. While abundances of both NaPi-llc and PiT2 were decreased, abundance of $\mathrm{NaPi}$-lla was increased (45). In addition, lipid composition and membrane fluidity was altered as well. Changes of the contents of sphingomyelin and glucosylceramide were reported to decrease membrane fluidity.

In contrast to potassium deficiency, potassium loading was shown to decrease urinary excretion of phosphate. Stimulation of total renal reabsorption of phosphate by potassium loading was shown to be dependent on intact parathyroid glands. Interestingly stimulation of total renal reabsorption of phosphate induced by intravenous injection of potassium has been associated with an increase of distal tubular reabsorption of phosphate (141).. In control animals no evidence for distal reabsorption was obtained.

\section{Metabolic Acidosis}

The increase in phosphate excretion that occurs with metabolic acidosis has at least two physiological roles. First, it provides urinary buffer to enhance the excretion of acids. Second, it reduces the extracellular burden of phosphate that occurs from mobilization of bone mineral (176). Chronic metabolic acidosis in humans causes negative calcium and phosphate balance that results from mobilization of bone mineral (176).

Phosphaturia occurs with metabolic acidosis induced by ammonium chloride, hydrochloric acid, or lactic acid, and is completely reversed by correction of acidemia (118). Interestingly, there is no consistent change in serum phosphate concentration. Thus the major factor that induces phosphaturia appears to be acidemia. The effects of metabolic acidosis on phosphate excretion occur in the absence of PTH (118).

Sensitivity to luminal $\mathrm{pH}$-values of $\mathrm{Na} / \mathrm{Pi}$-cotransporters localized at the proximal tubular brush border membranes may explain part of the phosphaturic response elicited by metabolic acidosis. In brush border 
membrane vesicles $\mathrm{Na} / \mathrm{Pi}$ cotransport activity is very sensitive to $\mathrm{pH}$ with acidic $\mathrm{pH}$ decreasing transport activity (10). The function of both, NaPi-lla and $\mathrm{NaPi}$-llc is decreased by an increase of extracellular proton concentration (98). Part of this inhibition is related to allosteric changes in the phosphate transporters, which inhibit sodium activation (312). In addition to the direct and immediate effects of $\mathrm{pH}$ on phosphate transporters, acidemia over time eventually reduces phosphate transport by mechanisms related to glucocorticoids that have been shown to reduce phosphate reabsorption (102, 318 ) or to elevated levels of FGF-23 (158)

Regulation of proximal tubular $\mathrm{Na} / \mathrm{Pi}$-cotransporters by metabolic acidosis has been studied in rats and mice. Studies in rats revealed a decrease of $\mathrm{NaPi}-l l a$ mRNA that was paralleled by a decrease of the amount of NaPi-lla proteins (8). In another study in rats kept on a low or normal phosphate diet, acidosis induced phosphaturia only in animals on normal phosphate intake and no decrease in NaPi-Ila, NaPi-Ilc or PiT2 expression was found in rats on low phosphate diet (310). Similarly, in mice, metabolic acidosis provoked a decrease of NaPi-llc and NaPi-lla mRNA expression, however, protein content of both $\mathrm{Na} / \mathrm{Pi}$-cotransporters was increased (230). Thus, at least in mice, metabolic acidosis induced phosphaturia cannot be explained by a downregulation of type $\| \mathrm{Na} / \mathrm{Pi}$-cotransporters.

\section{1,25-Dihydroxyvitamin $D_{3}$}

The active form of vitamin $D, 1,25$-dihydroxyvitamin $D_{3}\left(1,25-(O H)_{2} D_{3}\right)$, is primarily formed in kidney proximal tubules by $1 \alpha$-hydroxlases that are located in the inner mitochondrial membrane. The net serum concentration of 1,25 dihydroxyvitamin $D_{3}$ is determined by complex regulations of the $1 \alpha$ hydroxylase as well as 24-hydroxylase by PTH, FGF23 and dietary phosphate $(88,183)$. Under normal conditions 1,25 -dihydroxyvitamin $D_{3}$ appears to have no demonstratable effects on renal handling of phosphate, but rather on intestinal absorption of phosphate (207). A phosphaturic action of 1, 25$(\mathrm{OH})_{2} \mathrm{D}_{3}$ appears to be more indirect as increased levels of $1,25-(\mathrm{OH})_{2} \mathrm{D}_{3}$ stimulate release of FGF23 from bone that in turn inhibits reabsorption of phosphate. By using 1,25- $(\mathrm{OH})_{2} \mathrm{D}_{3}$ deficient rats, administration of 1,25 - 
$(\mathrm{OH})_{2} \mathrm{D}_{3}$ was shown to increase $\mathrm{NaPi}-$ lla abundance, likely occurring via a transcriptional mechanism (282).

Reduced dietary intake of phosphate increases $1 \alpha$-hydroxylase activity in proximal tubules and serum concentration of $1,25-(\mathrm{OH})_{2} \mathrm{D}_{3}$ (332). In animal models, increase of both activity and mRNA content of 1a-hydroxyalse was delayed by approximately $24 \mathrm{~h}$ after the onset of reduced dietary intake of phosphate. In hypophysectomized animals this increase was blunted and therefore appears to be dependent on growth hormones (285). The late onset of $1,25-(\mathrm{OH})_{2} \mathrm{D}_{3}$ production induced by low Pi-diet makes it unlikely that 1,25 $(\mathrm{OH})_{2} \mathrm{D}_{3}$ is involved in the rapid adaptive response to low Pi-diet. In agreement, an intact acute adaptive response of renal $\mathrm{Na} / \mathrm{Pi}$-cotransport has been demonstrated in 1a-hydroxylase knock out mice (51).

\section{Dietary Intake of Phosphate}

Renal reabsorptive capacity for phosphate varies and adapts profoundly in response to dietary intake of phosphate $(289,303)$. Phosphate restriction enhances and high phosphate diets reduce the intrinsic capacity of the kidney to reabsorb phosphate. It is useful to distinguish between phosphate restriction (short term) and phosphate depletion (over a long period of time). Renal adaptation to altered intake of dietary phosphate occurs rapidly -within hours- and specifically alters the rate of proximal tubular $\mathrm{Na} / \mathrm{Pi}$-cotransport $(177,181,249)$. Phosphate depletion represents a more severe state that requires 2-4 weeks of phosphate deprivation and is associated with impaired energy metabolism and multiple reabsorptive defects along the nephron, including those for glucose, amino acids, bicarbonate, and calcium (156). In contrast to reduced intake of phosphate by dietary content of phosphate, fasting provoked only minor changes of renal excretion of phosphate and $\mathrm{Na} / \mathrm{Pi}$-cotransport actitvity in brush border membrane vesicles (150).

The proximal tubule is the major nephron site at which adaptation to phosphate restriction occurs. Both early and late portions of the proximal tubule from both superficial and juxtamedullary nephrons are involved in adaptative changes (125). The effect of dietary adaptation on $\mathrm{Na} / \mathrm{Pi}$ cotransport has been demonstrated both in isolated proximal tubules (303) and isolated brush border membrane vesicles and is manifested by an 
increase in $V_{\max }$ without changes in $K_{m}$-value $(58,59,277)$. Rapid (two hours) adaptation to phosphate restriction leads to increased $\mathrm{Na} / \mathrm{Pi}$-cotransport in rat brush border vesicles due to an increase of $\mathrm{NaPi}$-lla abundance $(186,249)$. Similarly, rapid down-regulation of $\mathrm{Na} / \mathrm{Pi}$-cotransport and abundance of $\mathrm{NaPi}$ Ila protein is observed after intake of excessive phosphate $(186,249)$. As observed after PTH injection, acute down-regulation of $\mathrm{NaPi}$-lla protein induced by high Pi-diet involves endocytosis and lysosomal degradation of NaPi-lla proteins (151).

Short-term changes of dietary phosphate intake primarily affect abundance of $\mathrm{NaPi}$-lla protein, whereas changes in the abundance of NaPi-Ilc and PiT-2 $\mathrm{Na} / \mathrm{Pi}$-cotransporters are slower (309) and likely occur by different mechanisms. For instance, although apical content of NaPi-llc is reduced by high dietary phosphate, total cellular content was not altered, suggesting that the mechanism of regulation of $\mathrm{NaPi}-\| \mathrm{c}$ is distinct from the NaPi-lla cotransporter (265).Neither the nature nor the locus of possible phosphate signaling pathways that provoke proximal tubular adaptation of $\mathrm{Na} / \mathrm{Pi}$ cotransporters in response to changes in phosphate intake are known yet. Among the various candidates, PTH, calcitonin, vitamin D metabolites, thyroxine, growth hormone, FGF23, and, the pituitary gland have been discarded $(34,83)$. When directly introduced into the rat duodenum, phosphate elicited an increase of phosphate excretion within 15 min that was independent of altered serum levels of PTH, FGF23, serum phosphate concentration and was also not dependent on renal nerves $(32,161)$. Based on this data, a -yet unknown- intestinal endocrine factor (termed 'intestinal phosphatonin') was proposed that could participates in an intestine-renal signalling axis. However, it has also been shown, that contact with intestinal mucosa can be bypassed by intravenous injection of a phosphate bolus. Continuous infusion of phosphate into thyroparathyroidectomized rats adapted to low phosphate diet has been shown to down-regulate brush border membrane $\mathrm{Na} / \mathrm{Pi}$-cotransport within a short period of time (58). This suggests that serum concentration of phosphate may represent the signal for renal adaptation of $\mathrm{Na} / \mathrm{Pi}$-cotransport, and secondly that the signaling mechanisms may be intrinsic to the kidney itself (27). 


\section{SULFATE}

Inorganic sulfate is taken up by diet and is critical for several basic processes such as forming very stable disulfide bonds within or between proteins (e.g. in keratins), forming part of enzymes or vitamins such as coenzyme A, thiamine and biotin, or being part of redox systems such as glutathione and thioredoxins. Sulfate plays an important role in detoxification by the liver, and for the structural integrity of bone and cartilage.

The main source of sulfate is dietary intake of protein comprised of sulfurcontaining amino acids, mostly cysteine and methionine. Additional sources are water which may contain significant amounts of sulfate. Free inorganic sulfate is readily absorbed from diet in a $\mathrm{Na}^{+}$-dependent process occurring mostly in the small intestine and is mediated by mechanisms and molecules similar if not identical to renal reabsorption of inorganic sulfate (see below) $(97,223)$. Daily intake of sulfate has been reported to be in the range of 0.2 to $1.5 \mathrm{~g}(2.1-15.8 \mathrm{mmol}) /$ day (97).

Protein catabolism, mostly in liver, releases sulfate from cysteine and methionine containing proteins in parallel with elevated ureagenesis thereby correlating urinary sulfate and urea excretion $(114,133,252)$. Urinary sulfate excretion may be even used as a marker of catabolism of sulfur-containing proteins $(121,131)$.

\section{PLASMA SULFATE CONCENTRATION}

In plasma, inorganic sulfate concentrations range between 0.2 and $1.1 \mathrm{mmol} / \mathrm{l}$ with an average of about $0.6 \mathrm{mmol} / \mathrm{l}(22)$. The main source of inorganic sulfate in the body is dietary uptake and metabolism of the sulfur containing amino acids cysteine, methionine, and to a lesser extent homocysteine and taurine. In humans, low circulating sulfate levels are not associated with specific diseases, however, rare inborn disorders of organ and cell specific sulfate transporters have been reported to cause severe malformations such as diastrophic dysplasia, a disorder affecting primarily chondrocytes (127). 


\section{RENAL HANDLING OF SULFATE}

Because $\mathrm{SO}_{4}{ }^{2-}$ is freely filtered (113) the rate of urinary excretion is determined by the rate of reabsorption and secretion along the proximal tubule. Sulfate reabsorption is an active process, regulated, and saturable (182). With increasing intake, the filtered sulfate load exceeds the threshold for maximal tubular reabsorption and increasing amounts of sulfate appear in urine. Under normal dietary sulfate supply, the fractional excretion of sulfate is approximately $10 \%$ in dog (113), whereas in rat the fractional excretion is around $30 \%$ with plasma concentrations of sulfate of approximately $0.7-1$ $\mathrm{mmol} / \mathrm{L}(22,159,222)$.

The mechanisms by which sulfate is transported along the nephron have been thoroughly examined using micropuncture in vivo $(67,130,296,297,298$, $299,300,301,302,305)$, microperfusion of isolated tubules ex vivo (44), and isolation of vesicles of brush border and basolateral membranes (16, 116, $188,189,242,260,294)$. Several aspects have been reviewed recently (193, 200, 202, 203, 204).

Sulfate is actively transported in the proximal tubule across the luminal brush border membrane as well as via the basolateral membrane of cells (44, 67,189, 241, 260, 294, 296, 297, 298, 299, 300, 301, 302, 305). Collectively, many studies demonstrated using micropuncture, isolated brush border and basolateral membrane vesicles that sulfate transport occurs mostly by a $\mathrm{Na}^{+}-$ dependent transport process across the brush border membrane and by sulfate/anion exchange in the basolateral membrane (Figure 2).

Brush border membrane vesicle studies showed a $\mathrm{Na}^{+}$-dependent transport process with an estimated affinity for sulfate of approximately $600 \mu \mathrm{M}$ and for sodium with about $36 \mathrm{mM}(260,294)$. Because the Hill coefficient was close to 2 it was assumed that the transport process was electroneutral. Following the cloning of NaSi1 transport induced currents were demonstrated that are due to the cotransport of $3 \mathrm{Na}^{+}$ions per sulfate (48). The luminal, $\mathrm{Na}^{+}$-dependent transport process interacts with thiosulfate, selenate, chromate, and molybdate but not phosphate $(67,297)$.

The luminal membrane, however, has also an additional transport system mediating the exchange of intracellular sulfate for extracellular anions, most 
likely bicarbonate and oxalate. Thereby the proximal tubule is able to secrete sulfate into urine $(44,81,163,242,284)$. Whether the latter transport pathway characterized mostly in isolated brush border membrane vesicles has physiological relevance depends on the availability of intracellular and extracellular transport substrates. In mice lacking CFEX (possibly the molecular correlate of this transport activity) no sulfate related phenotype has been reported to date (see below).

In contrast, the basolateral transport process is mediated by an anion exchange mechanism releasing sulfate into the extracellular space in exchange for anions such as bicarbonate, oxalate or hydroxyl ions $(44,120$, $162,188)$. The transport mechanism is inhibited by the stilbene derivates DIDS and SITS, nonspecific inhibitors of various anion transport systems (16). Of note, the transport substrates and sensitivity of the luminal and basolateral sulfate exchangers are different suggesting that each transport systems are encoded by distinct genes.

\section{MOLECULAR IDENTIFICATION OF RENAL SULFATE TRANSPORTERS NaSi1 (SLC13A1)}

NaSi1 (NaS1, SLC13A1) was first identified by expression cloning from a rat kidney cDNA library in Xenopus oocytes and shown to mediate $\mathrm{Na}^{+}$dependent uptake of sulfate $(20,196)$. Homologues from other species including mouse and man have been further identified $(20,168)$. The human gene consists of 15 exons and is localized on chromosome 7q31-7q32 (168). The NaSi 1 protein consists of 595 amino acids and is predicted to form a protein with 13 transmembrane domains $(20,168)$.

Transport of sulfate by NaSi1 is electrogenic and kinetic analysis suggests that probably $3 \mathrm{Na}^{+}$ions are cotransported with one $\mathrm{SO}_{4}{ }^{2-}$ ion per transport cycle by NaSi1 (48). NaSi1 transports $\mathrm{SO}_{4}{ }^{2-}$, thiosulfates, and selenate with affinities in the range of $100-500 \mu \mathrm{M}$, respectively, and sodium with an apparent $\mathrm{Km}$ of about $20 \mathrm{mM}(48,196)$. Structural and phylogenetic features of NaSi1 have been reviewed in more detail elsewhere (200). NaSi1 is expressed predominantly in kidney and small intestine. There it 
localizes to the apical brush border membrane of early proximal tubule cells and enterocytes of the small intestine and possibly also colon $(20,228)$. Weak expression may occur also in testis, adrenal glands and adipose tissue. In rat and mouse kidney, NaSi1 immunostaining is predominant in the proximal convoluted tubule (S1 and S2 segments) and weaker in the straight proximal tubule (S3 segment). NaSi1 staining is found in cortical and juxtamedullary nephrons $(65,187)$.

Deletion of $\mathrm{NaSi} 1$ in mice demonstrated that apical $\mathrm{Na}^{+}$-dependent sulfate transport is completely accounted for by $\mathrm{NaSi}-1$ and mice display a sulfate losing phenotype (hypersulfaturia) (69). Hyposulfatemia is the consequence of both urinary sulfate losses as well as impaired intestinal uptake. NaSi1 deficient mice have been a useful tool to study the physiological roles of sulfate and the consequences of hyposulfatemia as exemplified by reduced fertility, growth retardation, impaired hepatic detoxification of drugs, changes in hepatic lipid metabolism, and impairment of CNS functions $(69,70,71,72$, $73,76,77,173,174)$. Thus, intestinal uptake and renal reabsorption of sulfate depend critically on the presence and activity of $\mathrm{NaSi}-1$.

\section{SAT1 (SLC26A1)}

SAT1 (SLC26A1) belongs to the family of SLC26 anion exchangers $(87,193,221)$. Several members of this family have been shown to transport sulfate, most notably SAT1 $(38,194$, DSTS (SLC26A2) $(127,147)$ and CFEX /PAT1 (Chloride-formate exchanger/ putative anion transporter 1 (SLC26A6) (144), and SLC26A11 (311).

SAT1 was identified by expression cloning (38). The protein consists of 703 amino acids and has 12 putative transmembrane domains. When expressed in heterologous expression systems SAT1 mediates the transport of a variety of anions including sulfate, bicarbonate, and oxalate. Chloride may also be transported but with low affinity and efficiency (157). This transport activity is mediated by an obligatory exchange mechanism where intracellular substrate is exchanged for extracellular substrate. The transporter interacts also with probenecid, selenate, phenol red, tungstate and DIDS. Whether these 
substances are only inhibitors or transport substrates has not been fully explored (38).

SAT1 mRNA has been detected in many organs including kidney, liver, small intestine, skeletal muscle and brain (38). In rodent kidney, SAT1 is localized to the basolateral membrane of the proximal tubule with more intense staining of proximal convoluted tubules (e.g. S1 and S2 segments) than straight proximal tubules (e.g. S3 segment) (146) paralleling the apical localization of NaSi1 in the same segments (187). The localization of SAT1 in human kidney has not been reported to date.

In vivo studies with sat1 deficient mice provided evidence for a primary defect in renal sulfate handling but not oxalate or bicarbonate (see below) suggesting that SAT1 serves mostly the transepithelial transport of sulfate (75). SAT1 KO mice show renal sulfate wasting and hyposulfatemia consistent with a major role of SAT1 in the release of sulfate from proximal tubule cells into the basolateral space. The physiological counter-ion is likely bicarbonate. Even though oxalate interacts with the transporter with a higher affinity, the very low concentrations measured in normal human subjects and animals (in the range of 1-5 $\mu \mathrm{M}$ ) and the high concentrations of bicarbonate (approx. $25 \mathrm{mM}$ ) at the basolateral membrane favour exchange of intracellular sulfate for extracellular bicarbonate (or chloride) (157). Interestingly, sat1 deficient mice also developed oxalate kidney stones, reminiscent of slc26a6 deficient mice (see below). The mechanism causing oxalate stones has not been elucidated to date.

\section{CFEX/PAT1 (SLC26A6)}

CFEX (SLC26A6, also known as PAT1) is expressed in the proximal tubule of the kidney and the small intestine and localizes to the apical brush border membrane (152). CFEX mediates the exchange of various anions including chloride, bicarbonate, oxalate, and also sulfate (144). Considering physiological concentrations and distribution (luminal vs intracellular) of these anions, sulfate is not a major substrate in vivo and might be rather excreted 
than reabsorbed by CFEX. Mice lacking CFEX $\left(S / c 26 a 6^{-1}\right)$ have no apparent abnormality of sulfate homeostasis but develop massive hyperoxaluria and oxalate kidney stones (143).

\section{REGULATION OF SULFATE EXCRETION \\ Dietary Adaptation to high and low Sulfate Intake}

Adaptive mechanisms in the proximal tubule are of primary importance in the regulation of systemic sulfate homeostasis. These adaptive changes in renal sulfate reabsorption in response to dietary sulfate intake are similar to those demonstrated for phosphate and allow for constant plasma sulfate concentrations. Dietary sulfate deprivation results in a significant decline of the renal sulfate clearance and the urinary excretion rate of sulfate $(26,199$, $226,255)$. Clearance experiments in guinea pigs fed for 6-10 days with lowsulfate diet $(0.13 \%)$ demonstrated $86-91 \%$ fractional sulfate reabsorption at normal plasma sulfate concentrations while animals on high-sulfate diet $(0.13 \%$ supplemented with $300 \mathrm{mg} / \mathrm{kg} /$ day sodium sulfate) decreased renal sulfate excretion to $55-70 \%$ (226). Similarly, dietary sulfate deprivation in rats exhibited decreased urinary excretion rates and renal clearance values after 8 days of treatment while serum sulfate concentrations were unchanged. In vitro transport studies in brush border membrane (BBM) and basolateral membrane (BLM) vesicles isolated from rats stabilized on either low methionine or control diets for 7-9 days showed an increase of the $V_{\max }$ for BBM sodium dependent sulfate transport in animals on low methionine diet (26). In contrast, in BBM vesicles of Nas1-deficient mice sodium sulfate transport was reduced by $90 \%$ (69). Thus, the increase in renal BBM sodium/sulfate cotransport is a key mechanism in the adaptive response to tubular sulfate handling while tubular secretion, if any, is negligible in rats and humans. More recent studies confirmed these findings and shed light on the cellular mechanisms involved. Rats treated with low methionine diet $(0 \%$ and $0.3 \%$ ) were able to maintain normal serum sulfate levels and exhibited marked increases in NaSi-1 cotransporter mRNA and protein levels (255). Accordingly, urinary sulfate excretion rate and renal sulfate clearance were significantly decreased approaching zero. However, animals on $0 \%$ 
methionine diet and normal serum sulfate levels were growth retarded with loss of muscle mass suggestive of maintained serum sulfate levels due to muscle catabolism. Animals fed with $0.3 \%$ methionine diet were able to maintain body and muscle weight indicating sufficient adaptive renal sulfate reabsorptive mechanisms. Animals on high methionine diet $(2.46 \%)$ showed unchanged serum sulfate levels associated with lower NaSi-1 mRNA abundance (255). Another study from Markovich et al. highlighted the crucial role of $\mathrm{NaSi}-1$ in regulation of plasma sulfate concentration by using different sulfate diets (199). High sulfate diet in rats resulted in a marked decrease of BBMV sodium/sulfate cotransport activity paralleled by a significant decrease in NaSi-1 mRNA and BBM protein abundance. Both studies from Markovich and Sagawa et al. concluded that $\mathrm{NaSi}-1$ plays a major role in maintaining serum sulfate concentrations within the physiological range, even $\mathrm{NaSi}-1$ alone may not be responsible for the raised sulfate excretion in animals on high sulfate diet suggestive of either similar absorptive mechanisms or additional secretory processes being involved. The regulation of Sat-1 (SLC26a1) and CFEX (SLC26a6) by dietary sulfate has not been explored to date.

\section{Thyroid Hormone}

Serum sulfate levels are decreased in hypothyroid patients and higher in hyperthyroid patients (283). Thyroid hormone ( $T_{3}$, triiodothyronine) increases the maximum transport capacity for sodium/ sulfate cotransport in mouse renal BBM vesicles while serum sulfate concentrations were unchanged (286). The absence of an effect of $T_{3}$ on serum sulfate levels may be due to increased cellular uptake and utilization of sulfate, inhibition of renal sulfate reabsorption in the distal nephron, reduced intestinal sulfate absorption, or a combination of all. Similarly, experimental hypothroidism in rats decreases serum sulfate concentrations, lowers renal fractional reabsorption of sulfate and creatinine clearance. Sodium-dependent sulfate uptake into BBMV is reduced while $K_{\mathrm{m}}$ values are not different (257). In contrast, there were no significant differences in $K_{\mathrm{m}}$ and $V_{\max }$ for the sulfate/ anion exchange process in basolateral membrane vesicles. NaSi-1 mRNA and protein levels were 
significantly reduced in hypothyroid rats indicating that hypothyroidism affects NaSi-1 mRNA and/or protein expression. The Nas1 promoter region contains $\mathrm{T}_{3}$ responsive elements (74).

\section{Vitamin $D_{3}$}

Renal sulfate reabsorption has been shown to be regulated by Vitamin $D_{3}$ status. Vitamin D-deficient rats develop hyposulfatemia, enhance fractional excretion of sulfate, and decrease renal sodium sulfate cotransport activity (93). The changes in sodium sulfate cotransport activity are caused by a decrease of $V_{\max }$ but not $K_{\mathrm{m}}$ of the transport system paralleled by reduction of both NaSi-1 cotransporter protein and mRNA levels. Vitamin $D_{3}$ supplementation corrects hyposulfatemia, normalizes fractional sulfate excretion, and normalizes NaSi-1 mRNA and protein levels. Most likely the active $1,25(\mathrm{OH})_{2} \mathrm{D}_{3}$, but not plasma calcium nor PTH levels are responsible for the alterations of NaSi-1 expression and activity in this model. 1,25$(\mathrm{OH})_{2} \mathrm{D}_{3}$ stimulates the transcriptional activation of the Nas1 promoter. However, Sat-1 mRNA and protein levels in the kidney and liver are not altered by vitamin $D_{3}$ deficiency (21). Mice lacking the vitamin $D$ receptor show a significant increase of urinary sulfate excretion by $40 \%$ paralleled by a fall in serum sulfate concentrations of $50 \%$ (39). NaSi-1 mRNA levels in the kidney are markedly decreased by $70 \%$ whereas intestinal NaSi-1 levels are not altered. The impact of vitamin $\mathrm{D}_{3}$ on NaSi-1 expression and sulfate metabolism is independent of its effect on calcium metabolism, since similar results were observed in these animals after normalization of blood calcium levels. In addition, treatment of wild-type mice with vitamin $D_{3}$ increases renal NaSi-1 mRNA abundance. Taken together, the data provide evidence that vitamin $D_{3}$ plays a crucial role in sulfate regulation by affecting renal $\mathrm{NaSi}-1$ expression.

\section{Glucocorticoids}

Glucocorticoids reduce renal sulfate reabsorption in rat, chicken and winter flounder $(247,248,254)$. Systemic treatment with the glucocorticoid, 
dexamethasone, decreased sodium dependent sulfate transport in chick renal BBM due to decreases in the maximum transport capacity $V_{\max }$ of $\sim 50 \%$ without changes in $K_{\mathrm{m}}$ or any other sulfate transport processes in either BBM or BLM (247). Similar results have been obtained from the marine winter flounder when treated with dexamethasone. Transepithelial sulfate transport in flounder renal tubule primary monolayer cultures treated with hydrocortisone was significantly higher than in cortisol-free tissue (247). Further evidence for the role of glucocorticoids in regulation of renal sulfate transport was provided from experiments in adrenalectomized rats that were either treated with methylprednisolone (MPL) or vehicle. NaSi-1 mRNA and protein levels were reduced in kidney cortex of MPL-treated animals that was paralleled by a 2-fold increase in urinary sulfate excretion and almost 3-fold increase in renal sulfate clearance (254). Changes in NaSi-1 mRNA and protein expression were time-dependent. mRNA levels were significantly decreased after 4 and $6 \mathrm{~h}$ after a single dose MPL. Protein expression was significantly diminished after 4, 6, and $12 \mathrm{~h}$ after MPL administration. Accordingly, the $V_{\max }$ for sodium sulfate cotransport in the BBM was significantly decreased whereas the apparent $K_{m}$ values or sulfate anion exchange in the BLM were unchanged in MPL-treated adrenalectomized rats (254). Finally, Beck and Markovich described the presence of five putative glucocorticoid responsive elements in the Nas1 promoter region (20) suggesting that glucocorticoids in fact directly regulate Nas1 gene transcription (202).

\section{Growth Hormone/Ageing}

Sulfate reabsorption by the kidney in young animals or humans is higher than in adult or aged individuals. In immature guinea pigs urinary sulfate excretion is low and and increases with aging (227). In young animals, low-sulfate diet did not appreciably stimulate $V_{\max }$ whereas a high-sulfate diet resulted in a decrease of $V_{\max }$ with no changes of $K_{\mathrm{m}}$ in any age group indicating that renal sulfate uptake responds to conditions with increased need of sulfate such as growth. In contrast, aged rats showed a higher sulfate excretion rate when compared to young animals without changes in serum sulfate concentrations 
(15). Cell culture studies using Madin-Darby canine kidney (MDCK) cells stably transfected with $\mathrm{NaSi}-1$ increased sodium sulfate cotransport after incubation with growth hormone $(\mathrm{GH})$ and insulin-like growth factor I (IGF-I) (172). A recent study examined changes in NaSi-1 mRNA and protein levels in old rats (22-23 months old) and compared them with adult rats (9-10 months). Both NaSi-1 mRNA and protein abundance were significantly lower in the aged animals and transiently increased after treatment with growth hormone (256). The data suggest that aging in animals is associated with a decrease of NaSi-1 mRNA and protein expression due to lower $\mathrm{GH}$ concentrations.

\section{Metabolic Acidosis}

Changes of blood $\mathrm{pH}$ such as metabolic acidosis cause adaptive changes in the activity of several proximal tubule transport proteins such as the apical sodium proton exchanger, the vacuolar $\mathrm{H}^{+}$-ATPase, and the basolateral sodium bicarbonate cotransporter $(3,56,239)$. Children with classic renal tubular acidosis have significantly elevated renal sulfate excretion when compared to weight-matched controls (57). Similarly, in rats induction of metabolic acidosis increases significantly the fractional sulfate excretion (104). Puttaparthi et al. investigated the influence of metabolic acidosis on NaSi-1 cotransport activity, protein and mRNA expression (243). Acute acidosis (624h) and chronic (10 days) acidosis were induced in rats with $\mathrm{NH}_{4} \mathrm{Cl}$ in drinking water and chow. Increased urinary sulfate excretion correlated with decreased sodium dependent sulfate cotransport activity in BBM vesicles of acidotic rats (2.4-fold). Accordingly, both cortical NaSi-1 mRNA abundance and BBM NaSi-1 protein expression were decreased by 2.8- and 2.2-fold, respectively. The reduction in sodium dependent sulfate cotransport activity was detectable after $24 \mathrm{~h}$, but not after $12 \mathrm{~h}$, of metabolic acidosis. The data suggest that decreased mRNA and protein abundance of NaSi-1 and reduced BBM NaSi-1 cotransport activity may play a crucial role in the inhibition of NaSi-1 activity by metabolic acidosis. In the marine teleost flounder acidosis similarly increases renal sulfate excretion (233). Primary cultures of the winter flounder renal proximal tubule epithelium were mounted in Ussing chambers 
and metabolic acidosis mimicked by reducing the interstitial $\mathrm{pH}$ to 7.1 (normally 7.7). Sulfate net secretion in flounder proximal tubule cells was stimulated by $41 \%$ in metabolic acidosis when compared to paired isohydric controls and prevented by administration of the carbonic anhydrase inhibitor methazolamide. Also, administration of EIPA (a pyrazine-ring substituted amiloride derivative blocking NHE3 activity) to the lumen blocked this stimulation. Thus, carbonic anhydrase and BBM sodium proton exchanger activity may be required in this model for the acute stimulation of sulfate secretion by acidosis. In summary, metabolic acidosis reduces the expression of the major BBM sodium sulfate cotransporter $\mathrm{NaSi}-1$ and thereby affects sulfate homeostasis.

\section{Hypokalemia}

Hypokalemia has been shown to modulate several proximal tubule transport proteins $(178,273)$. Rats that were treated for 7 days with a potassiumdeficient diet had hyposulfatemia, increased fractional sulfate excretion, and a significant decrease of the BBM sodium/sulfate cotransport activity (201). The reduction in BBM sodium/sulfate cotransport activity was correlated with decreases in cortical NaSi-1 mRNA and BBM protein expression. Accordingly, Xenopus oocytes injected with mRNA from $\mathrm{K}^{+}$-deficient rats showed a significant reduction in sodium sulfate cotransport but no changes in L-leucine uptake suggesting that in low- $\mathrm{K}^{+}$diet down-regulation of NaSi-1 mRNA and protein is the potential underlying mechanism involved.

\section{Pregnancy and postnatal Growth}

As described above, during postnatal growth renal sulfate reabsorption is increased $(170,227,234)$. In children an age-dependent curvilinear regression exists for serum sulfate concentrations showing highest serum sulfate levels at birth $(0.47 \mathrm{mmol} / \mathrm{l})$ which decrease constantly to $0.33 \mathrm{mmol} / \mathrm{l}$ during the following three years of life (60). In guinea pigs, the decrease in renal sulfate excretion with age was based on significantly decreased $V_{\max }$ values for sodium dependent sulfate cotransport in BBM while $K_{\mathrm{m}}$ values were not different (170). Using pregnant and non-pregnant animals $V_{\max }$ and $K_{\mathrm{m}}$ 
values for BBM sulfate transport were significantly higher in pregnant animals. In contrast, sulfate anion exchange in BLM was unchanged among the different age groups. However, in pregnant guinea pigs $K_{m}$ of the BLM sulfate transport was significantly higher while $V_{\max }$ was not different when compared to non-pregnant animals. A study looking at the ontogeny of renal sulfate transporter expression during postnatal maturation in 1 to 77 days old rats revealed that mRNA expression of both $\mathrm{NaSi}-1$ and Sat- 1 increase during the first 2 postnatal weeks (195). However, Sat-1 protein abundance increased in parallel while NaSi-1 protein levels remained steady. In conclusion, several studies indicate that sulfate is conserved in young and pregnant animals due to stimulated proximal tubule sulfate uptake as well as increased expression of both transporters involved in renal sulfate reabsorption, namely NaSi-1 and Sat-1, respectively. These changes may reflect conditions of increased need for sulfate substrates during growth and pregnancy.

\section{Membrane Fluidity}

The activity and kinetics of membrane transport proteins have been described to be affected by membrane fluidity. Sodium-dependent renal glucose and phosphate transport have been shown to be altered by changes in membrane fluidity $(179,280)$. In MDCK cells stably transfected with NaSi-1 preincubation with cholesterol significantly decreased the $V_{\max }$ for sodium dependent sulfate transport with no changes in $K_{\mathrm{m}}$ while addition of benzyl alcohol stimulated sulfate uptake by $20 \%$ (171). These changes correlated with decreased membrane fluidity, measured by the fluorescence polarization of 1,6-diphenyl 1,3,5-hexatriene (DPH), after incubation with cholesterol and increased membrane fluidity following administration of benzyl alcohol.

\section{Non-steroidal anti-inflammatory Drugs (NSAIDs)}

Non-steroidal anti inflammatory drugs (NSAIDs) such as Indomethacin, Salicylic acid, Tiaprofenic acid, and Ibuprofen modulate renal sulfate clearance $(24,25,66,218,219,220,253)$. Rats infused with Ibuprofen or Indomethacin demonstrated a markedly increased renal sulfate clearance (218). Many of these drugs affect prostaglandin synthesis. PGE2 alone does not alter renal sulfate clearance whereas PGE2 adminstration is able to 
prevent the effects of Ibuprofen or Indomethacin on renal sulfate clearance. Moreover, Indomethacin, Ibuprofen, and Tiaprofenic acid may directly affect renal sulfate transport in rat kidney BBM and BLM vesicles (24). The effects of Ibuprofen on basolateral sulfate transport are controversial. Treatment of rats resulted in a decrease of the sodium-dependent sulfate cotransport capacity in BBM vesicles with unchanged $K_{\mathrm{m}}$. In contrast, BLM sulfate transport was not affected. The decreased BBM sulfate transport was paralleled by a significant down-regulation of NaSi-1 mRNA and protein expression (253). Among all three NSAIDs, Indomethacin has the strongest inhibitory effect on renal sulfate handling. Also effects of Salicylic acid on renal sulfate transport are controversial. Direct incubation of BBM and BLM vesicles demonstrated significantly lower transport of sulfate whereby the $K_{\mathrm{i}}$ of Salicylic acid was much lower for BLM transport (66). However, part of these data is in contrast to previous studies where Salicylic acid did not inhibit sulfate transport across the BLM in micropuncture studies (301). Thus, NSAID affect renal sulfate transport, but the mechanim(s) underlying this effect have not been clarified.

\section{Chronic renal Failure}

Hypersulfatemia as well as hyperphosphatemia are present in patients with chronic renal failure $(101,212,213,214,283)$. In patients on maintenance hemodialysis an eight-fold increase of plasma sulfate concentrations is observed (192). Similar observations were made in children with chronic kidney disease (212). Here, plasma sulfate concentrations were inversely correlated with glomerular filtration rate and highest in children treated with regular dialysis. In rats with experimental chronic renal failure (subtotal nephrectomy), hypersulfatemia was detectable as early as three weeks after subtotal nephrectomy, rose further after six weeks and was paralleled by twofold increase of fractional renal sulfate excretion (94). In these kidneys, $\mathrm{NaSi}-1$ and Sat-1 total protein expression was decreased due to loss of functional kidney tissue while relative NaSi-1 cotransporter abundance was increased. Also hypersulfatemia despite of increased renal sulfate excretion could not be clearly explained. Human studies suggest a role for hypersulfatemia in the development of hyperparathyroidism (214). Patients with chronic renal failure demonstrated a positive correlation between plasma 
sulfate and serum creatinine concentrations. In contrast, ionized calcium was inversely correlated with phosphate but also sulfate and parathyroid hormone. Calcium is able to bind sulfate and build calcium sulfate complexes. The resultant fall of ionized calcium might stimulate parathyroid hormone secretion by the parathyroid glands. Accordingly, in children on hemodialysis hyperparathyroidism occurs with even normal calcium levels (211). Taken together, hypersulfatemia in chronic renal failure might play a role in the development of secondary hyperparathyroidism and renal osteodystrophy by aggravating complex formation with calcium.

\section{Heavy Metals}

Heavy metal intoxication can result in a generalized dysfunction of the proximal tubule including proteinuria, glucosuria, phosphaturia, and sulfaturia $(128,215,237,307)$. The effect of several heavy metals on both renal sulfate transport proteins, NaSi-1 and Sat-1, respectively was examined $(197,198)$. Mercury strongly inhibited sodium dependent sulfate cotransport in Xenopus oocytes by decreasing both $V_{\max }$ and $K_{\mathrm{m}}$ of sulfate transport by NaSi-1 (197). Lead also markedly inhibited NaSi-1 mediated sulfate uptake, however, only $V_{\max }$ was decreased while $K_{\mathrm{m}}$ was unchanged. In contrast to Mercury, this inhibition was fully reversible. Compared to Mercury and Lead, Cadmium contributed to a small decrease in $V_{\max }$ and thus to a weak inhibition of NaSi-1 transport, which was fully reversible similar to lead. Of note, a previous study performed in rats demonstrated no changes in sulfate uptake in Cadmiumtreated animals (128). Similar to mercury, chromium also inhibited $\mathrm{NaSi}-1$ by decreasing both $V_{\max }$ and $K_{\mathrm{m}}$ of sulfate transport by approximately 7 -fold which was again fully reversible. Similar to $\mathrm{NaSi}-1$, the activity of the sulfate transporter Sat-1 was also inhibited by the heavy metals mercury, lead, cadmium, and chromium (197). Mercury inhibited Sat-1 mediated sulfate transport in Xenopus oocytes by reduction of $V_{\max }$ by 8-fold with no changes of $K_{\mathrm{m}}$ and was similar to NaSi-1 not reversible by simple washout. In contrast to NaSi-1, lead did not affect Sat-1 mediated sulfate uptake. Relatively high millimolar concentrations of cadmium were needed to induce significant inhibition of sulfate uptake by reducing $V_{\max }$ but not $K_{\mathrm{m}}$. Chromium only affected $K_{\mathrm{m}}$ but not $V_{\max }$ of Sat-1 sulfate uptake. 


\section{Figure legends}

Figure 1: Model of a proximal tubule cell depicting transport pathways of phosphate across the luminal and basolateral membrane. On the luminal brush border membrane at least three transporters exist that can mediate sodium-dependent phosphate transport. The $\mathrm{Na}^{+}$-dependent uptake of phosphate from primary urine is mediated by NaPi-Ila, NaPi-Ilc and PiT-2. The relative contribution of these three phosphate transporters may differ among different species. These transporters are energized by the membrane potential and $\mathrm{Na}^{+}$gradient generated by basolateral $\mathrm{Na}^{+} / \mathrm{K}^{+}$-ATPases. Phosphate exits proximal tubular cells across the basolateral membrane by a yet unknown transport pathway.

\section{Figure 2}

Model of a proximal tubule cell (early proximal tubule) depicting transport pathways of sulfate across the luminal and basolateral membrane. On the luminal brush border membrane at least two transporters exist that can mediate sulfate transport. The $\mathrm{Na}^{+}$-dependent uptake of sulfate from primary urine is mediated by the NaSi sulfate transporter. This transporter is energized by the membrane potential and $\mathrm{Na}^{+}$gradient generated by basolateral $\mathrm{Na}^{+}, \mathrm{K}^{+}-$ ATPases. Sulfate may also be excreted into primary urine by an anion exchanger, most likely CFEX, that transports sulfate in exchange for oxalate, chloride or bicarbonate. This transport pathway is also linked to $\mathrm{Na}^{+}-\mathrm{H}^{+}-$ exchange mediated mostly by NHE3. Sulfate exits proximal tubular cells across the basolateral membrane in exchange for extracellular anions through the SAT1 anion exchanger. Intracellular bicarbonate is excreted into the basolateral space by the $\mathrm{NBCe} 1$ electrogenic $\mathrm{Na}^{+}-\mathrm{HCO}_{3}{ }^{-}$-cotransporter. Also this transport process is linked to the NHE3 transporter and carbonic anhydrases generating bicarbonate. 


\section{ACKNOWLDGMENTS}

Work performed in our own laboratories was supported in part by funding from the Swiss National Science Foundation. The authors thank past and present members for their invaluable contributions to many of the reported studies. 


\section{References}

1.Abbraham MI, Woods R, Breedlove DK, Kempson SA. Renal adaptation to low-phosphate diet in diabetic rats. Am J Physiol 262: F731-F736, 1992.

2.ADHR Consortium. Autosomal dominant hypophosphataemic rickets is associated with mutations in FGF23. Nat Genet 26: 345-348, 2000.

3.Akiba T, Rocco VK, Warnock DG. Parallel adaptation of the rabbit renal cortical sodium/proton antiporter and sodium/bicarbonate cotransporter in metabolic acidosis and alkalosis. J Clin Invest 80:308-315, 1987.

4.Alcalde Al, Sarasa M, Raldua D, Aramayona J, Morales R, Biber J, Murer H, Levi M, Sorribas V. Role of thyroid hormone in regulation of renal phosphate transport in young and aged rats. Endocrinology 140: 1544-1551, 1999.

5. Alpern RJ. Cell mechanisms of proximal tubule acidification. Physiol Rev 70:79-114, 1990.

6. Amatschek S, Haller M, Oberbauer, R. Renal phosphate handling in human-what can we learn from hereditary hypophosphatemias? Eur J Clin Invest 40:552-560, 2010.

7. Amanzadeh J, Reilly RF. Hypophosphatemia : an evidence based approach to its clinical consequences and management. Nat Cli Pract Nephrol 2: 136-148, 2006.

8. Ambühl PM, Zajicek HK, Wang H, Puttaparthi K, Levi M. Regulation of renal phosphate transport by acute and chronic metabolic acidosis in the rat.

Kidney Int 53:1288-98, 1988.

9. Amiel C, Kuntziger H, Richet G. Micropunture study of handling of phosphate by proximal and distal nephron in normal and parathyroidectomized rat. Evidence for distal reabsorption. Pflügers Arch 317: 93-109, 1973. 
10.Amstutz M, Mohrmann M, Gmaj P, Murer H. Effect of $\mathrm{pH}$ on phosphate transport in rat renal brush border membrane vesicles. Am J Physiol 248: F705-F710, 1985.

11. Bacic D, Capuano P, Baum M, Zhang J, Stange G, Biber J, Kaissling B, Moe OW, Wagner CA, Murer $\mathrm{H}$. Activation of dopamine D1-like receptors induces acute internalization of the renal $\mathrm{Na}$ /phosphate cotransporter $\mathrm{NaPi}$-lla in mouse kidney and OK-cells. Am J Physiol 288: F740-F747, 2005.

12. Bacic D, Hernando N, Traebert M, Lederer E, Völkl H, Biber J, Kaissling B, Murer $\mathrm{H}$. Regulation of the renal type lla $\mathrm{Na} / \mathrm{Pi}$ cotransporter by cGMP. Pflügers Arch-Europ J Physiol 443: 306-313, 2001.

13. Bai XY, Miao D, Goltzman D, Karapalis AC. The autosomal domiant hypophosphatemic rickets $\mathrm{R} 176 \mathrm{Q}$ mutation in fibroblast growth factor 23 resists proteolytic cleavage and enhances in vivo biological potency. $J$ Biol Chem 278: 9843-9849, 2003.

14. Bailly C, Roinel N, Amiel C. PTH-like glucagon stimulation of $\mathrm{Ca}$ and $\mathrm{Mg}$ reabsorption in Henle's loop of the rat. Am J Physiol 246:F205-F212, 1984.

15. Bakhtian S, Kimura RE, Galinsky RE. Age-related changes in homeostasis of inorganic sulfate in male F-344 rats. Mech Ageing Dev 66:257-267,1993.

16. Bastlein $\mathrm{C}$, Burckhardt $\mathrm{G}$. Sensitivity of rat renal luminal and contraluminal sulfate transport to DIDS. Am J Physiol Renal Fluid Electrolyte Physiol 250: F226-F234, 1986.

17.Baum M, Schiavi S, Dwarakanath V, Quigley R: Effect of fibroblast growth factor-23 on phosphate transport in proximal tubules. Kidney Int 68:11481153, 2005.

18.Beach RE, Schwab SJ, Brazy PC, Dennis VW. Norepinephrin increases $\mathrm{Na}-\mathrm{K}-\mathrm{ATPase}$ and solute transport in rabbit proximal tubules. Am $\mathrm{J}$ Physiol 252: F215-F220, 1987.

19.Beck L, Karapalis AC, Amizuka N, Hewson AS, Ozawa H, Tennenhouse HS. Targeted inactivation of Npt2 in mice leads to severe renal phosphate wasting, hypercalciuria, and skeletal abnormalities. Proc Natl Acad Sci (USA) 95: 5372-5377, 1998.

20.Beck L, Markovich $\mathrm{D}$. The mouse $\mathrm{Na}(+)$-sulfate cotransporter gene Nas1. Cloning, tissue distribution, gene structure, chromosomal assignment, and transcriptional regulation by vitamin D. J Biol Chem 275:11880-11890, 2000.

21. Beck L, Silve C. Molecular aspects of renal tubular handling and regulation of inorganic sulfate. Kidney Int 59:835-845, 2001. 
22. Becker EL, Heineman HO, Igarashi K, Hodler JE, Gershberg H. Renal mechanisms for the excretion of inorganic sulfate in man. $J$ Clin Invest 39:1909-1913, 1960.

23.Beers KW, Thompson MA, Chini EN, Dousa TP. Beta estradiol inhibits Na$\mathrm{Pi}$ cotransport across renal brush border membranes from ovarectomized rats. Biochem Biophys Res Commun 221: 442-445, 1996.

24. Benincosa LJ, Morris ME. Inhibition of sulfate transport in rat kidney membrane vesicle preparations by nonsteroidal antiinflammatory drugs. Drug Metab Dispos 21:750-752,1993.

25. Benincosa LJ, Morris ME. Tiaprofenic acid inhibits the renal reabsorption of sulfate in rats. Prostaglandins Leukot Essent Fatty Acids 49:503-508, 1993.

26. Benincosa LJ, Sagawa K, Morris ME. Renal adaptation to altered dietary sulfate in rats. J Pharmacol Exp Ther 272:248-255, 1995.

27. Bergwitz C, Jüppner H. Phosphate sensing. Adv Chronic Kidney Dis 18: 132-144, 2011.

28. Bergwitz C, Roslin NM, Tieder M, Loredo-Osti JC, Bastepe M, Abu-Zahra H, Frappier D, Burkett K, Carpenter TO, Anderson D, Garabedian M, Sermet I, Fujiwara TM, Morgan K, Tenenhouse HS, Juppner H. SLC34A3 mutations in patients with hereditary hypophosphatemic rickets with hypercalcuria predict a key role for the sodium-phosphate cotransporter NaPi-Ilc in maintaining phosphate homeostasis. Am J Hum Genet 78:179-192, 2005.

29. Berndt T, Bielesz B, Craig TA, Tebben PJ, Bacic D, Wagner CA, O'Brien S, Schiavi S, Biber J, Murer H, Kumar R. Secreted frizzled-related protein-4 reduces sodium-phosphate co-transporter abundance and activity in proximal tubule cells. Pflügers Arch 451: 579-587, 2006.

30. Berndt T, Craig TA, Bowe AE, Vassiliadis J, Reczek D, Finnegan R,. Jan De Beur SM, Schiavi SC, Kumar R. Secreted frizzles-related protein 4 is a potent tumor-derived phosphaturic agent. J Clin Invest 112: 785-794, 2003.

31. Berndt T, Kumar R. Phosphatonins and the regulation of phosphate homeostasis. Annu Rev Physiol 69: 341-359, 2007.

32.Berndt T, Thomas LF, Craig TA, Sommer S, Li X, Bergstralh EJ, Kumar R. Evidence for a signaling axis by which intestinal phosphate rapidly modulates renal phosphate reabsorption. Proc Natl Acad Sci (USA) 104:11085-11090, 2007.

33. Berndt TJ, Knox FG. Proximal tubule site of inhibition of phosphate reabsorption by calcitonin. Am J Physiol 246: F927-F930, 1984. 
34. Berndt TJ, Knox FG. Renal regulation of phosphate excretion. The Kidney:Physiology and Pathphysiology. New York Raven Press, 1992, p.2511-2532.

35. Beutner EH, Munson PL. Time course of urinary excretion of inorganic phosphate by rats after parathyroidectomy and after injection of parathyroid extracts. Endocrinology 66: 610-616, 1960.

36. Bevington A, Kemp GJ, Graham R, Russell G. Phosphate -sensitive enzymes: a possible molecular basis for cellular disorders of phosphate metabolism. Clin Chem Enzyme Comms 4: 235-257, 1992.

37. Bielesz B, Bacic D, Honegger K, Biber J, Murer H, Wagner CA. Unchanged expression of the sodium-dependent phosphate cotransporter $\mathrm{NaPi}$-lla despite diurnal changes in renal phosphate excretion. Pflügers Arch 452: 683-689, 2006.

38.Bissig M, Hagenbuch B, Stieger B, Koller T, Meier PJ. Functional expression cloning of the canalicular sulfate transport system of rat hepatocytes. J Biol Chem 269: 3017-3021, 1994.

39.Bolt MJ, Liu W, Qiao G, Kong J, Zheng W, Krausz T, Cs-Szabo G, Sitrin MD, Li YC. Critical role of vitamin D in sulfate homeostasis: regulation of the sodium-sulfate cotransporter by 1,25-dihydroxyvitamin D3. Am J Physiol Endocrinol Metab 287:E744-E749, 2004.

40.Boross M, Kinsella J, Cheng L, Sacktor B. Glucocorticoids and metabolic acidosis-induced renal transports of inorganic phosphate, calcium and $\mathrm{NH} 4$. Am J Physiol 250: F827-F833, 1986.

41.Brazy PC, Gullans SR, Mandel LJ, Dennis VW. Metabolic requirement for inorganic phosphate by the rabbit proximal tubule: evidence for a Crabtree effect. J Clin Invest 70: 53-62, 1982.

42.Brazy PC, Mandel LJ, Gullans SR, Soltoff SP. Interactions between phosphate and oxidative metabolism in proximal tubules. Am J Physiol 247: F575-F581, 1984.

43.Brazy PC, Mandel LJ. Does availability of inorganic phosphate regulate cellular oxidative metabolism ? News Physiol Sci 1: 100-103, 1986.

44.Brazy, PC, Dennis VW. Sulfate transport in rabbit proximal convoluted tubules: presence of anion exchange. Am J Physiol 241: F300-F307, 1981.

45.Breusegem SY, Takahashi H, Giral-Arnal H, Wang X, Jiang T, Verlander JW, Wilson P, Miyazaki-Anzai S, Sutherland E, Caldas Y, Blaine JT, Segawa $\mathrm{H}$, Miyamoto KI, Barry NP, Levi M. Differential regulation of the renal sodium- 
phosphate cotransporters $\mathrm{NaPi}-\mathrm{lla}, \mathrm{NaPi}-\mathrm{Ilc}$, and $\mathrm{PiT}-2$ in dietary potassium deficiency. Am J Physiol 297: F350-F361, 2009.

46. Burnett S, Gunawardene S, Bringhurst F, Jüppner H, Lee H, Finkelstein J. Regulation of C-terminal and intact FGF23 by dietary phosphate in men and women. J Bone Miner Res 21: 1187-1196, 2006.

47.Busch AE, Schuster A, Waldegger S, Wagner CA, Zempel G, Broer S, Biber J, Murer $\mathrm{H}$, Lang $\mathrm{F}$. Expression of a renal type I sodium/phosphate transporter (NaPi-1) induces a conductance in Xenopus oocytes permeable for organic and inorganic anions. Proc Natl Acad Sci (USA) 83:5347-5351, 1996.

48.Busch, Waldegger, Herzer, Biber, Markovich, Murer, Lang. Electrogenic cotransport of $\mathrm{Na}+$ and sulfate in Xenopus oocytes expressing the cloned $\mathrm{Na}+\mathrm{SO} 42$ - transport protein NaSi-1. J Biol Chem 269: 12407-12409, 1994.

49.Capuano P, Bacic D, Roos M, Gisler SM, Stange G, Biber J, Kaissling B, Weinman EJ, Shenolikar S, Wagner CA, Murer H. Defective coupling of apical PTH receptors to phospholipase $\mathrm{C}$ prevents internalization of the $\mathrm{Na}$ phosphate cotransporter NaPi-lla in NHERF1 deficient mice. Am J Physiol 292:C927-C934, 2007.

50.Capuano P, Bacic D, Stange G, Hernando N, Kaissling B, Pal R, Kocher $\mathrm{O}$, Biber $\mathrm{J}$, Wagner $\mathrm{CA}$, Murer $\mathrm{H}$. Expression and regulation of the renal $\mathrm{Na}$ /phosphate cotransporter NaPi-lla in a mouse model deficient for the PDZ protein PDZK1. Pflügers Arch 449: 392-402, 2005.

51.Capuano P, Radanovic T, Wagner CA, Bacic D, Kato S, Uchiyama Y, StArnoud $\mathrm{R}$, Murer $\mathrm{H}$, Biber $\mathrm{J}$. Intestinal and renal adaptation to a low- $\mathrm{P}_{\mathrm{i}}$ diet of type II Na-Pi cotransporters in Vitamin D receptor- and $1 \alpha-O H a s e-d e f i c i e n t$ mice. Am J Physiol 288: C429- C434, 2005.

52. Carney S, Thompson L. Acute effect of calcitonin on rat renal electrolyte transport. Am J Physiol 240: F12-F16, 1981.

53.Carpenter TO, Ellis BK, Insogna KL, Philbrick WM, Sterpka J, Shimkets R. Fibroblast growth factor 7: An inhibitor of phosphate transport derived from oncogenic osteomalacia-causing tumors. J Clin Endocrinol Metab 90: 10121020, 2005.

54.Caverzasio J, Montessuit C, Bonjour JP. Stimulatory effect of insulin-like growth factor 1 on renal $\mathrm{Pi}$ transport and 1,25-dihydroxy-vitamin D3. Endocrinology 127: 453-459, 1990.

55.Chabardes D, Gagnan-Brunette M, Imbert-Teboul M, Gontcharevskaia O, Montegut M, Clique A, Morel F. Adenylate cyclase responsiveness to hormones in various portions of the human nephron. J Clin Invest 65: 439$448,1980$. 
56. Chambrey R, Paillard M, Podevin RA. Enzymatic and functional evidence for adaptation of the vacuolar $\mathrm{H}(+)$-ATPase in proximal tubule apical membranes from rats with chronic metabolic acidosis. J Biol Chem 269: 3243$3250,1994$.

57.Chan JC. Urinary sulfate excretion in children with classic renal tubular acidosis. Nutr Metab 22:257-61,1978.

58.Cheng L, Dersch C, Kraus E, Spector D, Sacktor B. Renal adaptation to phosphate load in the acutely thyroparathyroidectomized rat: rapid alteration in brush border membrane phosphate transport. Am J Physiol 246: F488F494, 1984

59.Cheng L, Liang CT, Sacktor B. Phosphate uptake by renal membrane vesicles of rabbits adapted to high and low phosphorous diets. Am J Physiol 245: F175-F180, 1983.

60.Cole DE, Scriver CR. Age-dependent serum sulfate levels in children and adolescents. Clin Chim Acta 107:135-139, 1980.

61.Forster IC, Hernando N, Biber J, Murer H. Phosphate transporters of the SLC20 and SLC34 families. Molec Aspects Med 34: 386 -395, 2013.

62.Cunningham R, Biswas R, Brazy M, Steplock D, Shenolikar S, Weinman EJ. Signaling pathways utilized by PTH and dopamine to inhibit phosphate transport in mouse renal proximal tubule cells. Am J Physiol 296: F355-F361, 2009.

63.Cunningham R, Biswas R, Steplock D, Shenolikar S, Weinman E. Role of NHERF and scaffolding proteins in proximal tubule transport. Urol Res 38: 257-262, 2010.

64.Custer M, Meier F, Schlatter E, Greger R, Garcia-Perez A, Biber J, Murer $\mathrm{H}$. Localization of $\mathrm{NaPi}-1$, a NaPi-cotransporter in rabbit kidney proximal tubules. Pflügers Arch 424:203-209, 1993.

65.Custer M, Murer H, Biber J. Nephron localization of $\mathrm{Na} / \mathrm{SO} 4$-cotransportrelated mRNA and protein. Pflugers Arch 429:165-168, 1994.

66.Darling IM, Mammarella ML, Chen Q, Morris ME. Salicylate inhibits the renal transport of inorganic sulfate in rat membrane vesicle preparations. Drug Metab Dispos 22:318-323, 1994.

67.David C, Ullrich KJ. Substrate specificity of the luminal Na-dependent sulphate transport system in the proximal renal tubule as compared to the contraluminal sulphate exchange system. Pflügers Arch 421: 455-465, 1992.

68.Davidoff M, Caffier H, Schiebler TH. Steroid hormone binding receptors in the rat kidney. Histochemistry 69: 39-48, 1988. 
69.Dawson PA, Beck L, Markovich D. Hyposulfatemia, growth retardation, reduced fertility, and seizures in mice lacking a functional NaSi-1 gene. Proc Natl Acad Sci (USA) 100:13704-13709, 2003.

70.Dawson PA, Choyce A, Chuang C, Whitelock J, Markovich D, Leggatt GR. Enhanced tumor growth in the NaS1 sulfate transporter null mouse. Cancer Sci 101: 369-373, 2010.

71.Dawson PA, Gardiner B, Grimmond S, Markovich D. Transcriptional profile reveals altered hepatic lipid and cholesterol metabolism in hyposulfatemic NaS1 null mice. Physiol Genomics 26: 116-124, 2006.

72.Dawson PA, Gardiner B, Lee S, Grimmond S, Markovich D. Kidney transcriptome reveals altered steroid homeostasis in NaS1 sulfate transporter null mice. J Steroid Biochem Mol Biol 112: 55-62, 2008.

73.Dawson PA, Huxley S, Gardiner B, Tran T, McAuley JL, Grimmond S, McGuckin MA, Markovich D. Reduced mucin sulfonation and impaired intestinal barrier function in the hyposulfataemic NaS1 null mouse. Gut 58: 910-919, 2009.

74.Dawson PA, Markovich D. Transcriptional regulation of the sodium-sulfate cotransporter NaS(i)-1 gene. Cell Biochem Biophys 36:175- 182, 2002.

75.Dawson PA, Russell CS, Lee S, McLeay SC, van Dongen JM, Cowley DM, Clarke LA, Markovich D. Urolithiasis and hepatotoxicity are linked to the anion transporter Sat1 in mice. J Clin Invest 120: 706 - 712, 2010.

76. Dawson PA, Steane SE, Markovich D. Behavioural abnormalities of the hyposulphataemic Nasi1 knock-out mouse. Behav Brain Res 154: 457-463, 2004.

77.Dawson PA, Steane SE, Markovich D. Impaired memory and olfactory performance in NaSi-1 sulphate transporter deficient mice. Behav Brain Res 159: 15-20, 2005.

78.Debska-Slizien A, Ho P, Drangiova R, Baines AD. Endogenous renal dopamine production regulates phosphate excretion. Am J Physiol 266: F858F867, 1994

79.DeFronzo RA, Cooke CR, Andres R, Faloona R, Davis PJ. The effect of insulin on renal handling of sodium, potassium, calcium, and phosphate in man. J Clin Invest 55: 845-855, 1975.

80.Dehghan A, Köttgen A, Yang Q, Hwang SJ, Kao WL, Rivadeneira F, Boerwinkle E, Levy D, Hofman A, Astor BC, Benjamin EJ, van Duijn CM, Witteman JC, Coresh J, Fox CS. Association of three genetic loci with uric acid concentration and risk of gout: a genome-wide association study. Lancet 372: 1953-1961, 2008. 
81.Dennis VW, Brazy PC. Divalent anion transport in isolated renal tubules. Kidney Int 22: 498-506, 1982.

82.Dennis VW, Woodhall PB, Robinson RR. Characteristics of phosphate transport in isolated proximal tubules. Am J Physiol 231: 979-985, 1976.

83.Dennis VW. Phosphate Homeostasis. Comprehensive Physiology. 17851815, 2011.

84.DeToledo FGS, Thompson MA, Bolliger C, Tyce GM, Dousa TP. Lglutamyl-L-DOPA inhibits Na-phosphate cotransport across renal brush border membranes and increases renal excretion of phosphate. Kidney Int 55: 1832-1842, 1999.

85.Dobbie H, Unwin RJ, Faria NJR, Shirley DG: Matrix extracellular phosphoglycoprotein causes phosphaturia in rats by inhibiting tubular phosphate reabsorption. Nephrol Dial Tranplant 23:730-733, 2008.

86.Dobrinskikh E, Giral H, Caldas YA, Levi M, Doctor RB. Shank2 redistributes with NaPilla during regulated endocytosis. Am J Physiol Cell Physiol 299: C1324- C1334, 2010.

87.Dorwart MR, Shcheynikov N, Yang D, Muallem S. The solute carrier 26 family of proteins in epithelial ion transport. Physiology 23:104-114, 2008.

88.Dusso AS, Brown A J, Slatopolsky E. Vitamin D. Am J Physiol 289: F8F28, 2005.

89.Faroqui S, Levi M, Soleimani M, Amlal H. Estrogen downregulates the proximal tubule type lla sodium phosphate cotransporter causing phosphate wasting and hypophosphatemia. Kidney Int 73: 1141-1150, 2008.

90.Farrow EG, Davis SI, Summers LJ, White KE. Initial FGF23 mediated signalling occurs in the distal convoluted tubule. J Am Soc Nephrol 20: 955960, 2009.

91.Farrow EG, White KE. Recent advances in renal phosphate handling. Nature Rev Nephrol 6: 207-217, 2010.

92.Feng JQ, Ye L, Schiavi S. Do osteocytes contribute to phosphate homeostasis? Curr Opin Nephrol Hypertens 18: 285-291, 2009.

93.Fernandes I, Hampson G, Cahours X, Morin P, Coureau C, Couette S, Prie $\mathrm{D}$, Biber J, Murer H, Friedlander G, Silve C. Abnormal sulfate metabolism in vitamin D-deficient rats. J Clin Invest 100: 2196-2203, 1997. 
94.Fernandes I, Laouari D, Tutt P, Hampson G, Friedlander G, Silve C. Sulfate homeostasis, NaSi-1 cotransporter, and SAT-1 exchanger expression in chronic renal failure in rats. Kidney Int 59:210-221, 2001.

95.Ferrari S, Bonjour JP, Rizzoli R. Fibroblast growth factor-23 relationship to dietary phosphate and renal phosphate handling in healthy young men. J Clin Endocrinol Metab 90: 1519-1524, 2005.

96. Fischer JA, Blum JW, Binswanger U. Acute parathyroid hormone response to epinephrine in vivo. J Clin Invest 52: 2434-2440, 1973.

97.Florin T, Neale G, Gibson GR, Christl SU, Cummings JH. Metabolism of dietary sulphate: Absorption and excretion in humans. Gut 32:766-773, 1991.

98.Forster IC, Hernando N, Biber J, Murer H. Phosphate transport kinetics and structure-function relationships of SLC34 and SLC20 proteins. Current Topics in Membranes 70: 313-355, 2012.

99.Forster IC, Kohler K, Biber J, Murer H. Forging the link between structure and function of electrogenic cotransporters: the renal type lla $\mathrm{Na} / \mathrm{Pi}$ cotransporter as a case study. Prog Biophys Mol Biol 80: 69-108, 2002.

100.Freeman D, Bartlett S, Radda G, Ross B. Energetics of sodium transport in the kidney saturation transfer 31P-NMR. Biochim Biophys Acta 762: 325336, 1983.

101.Freeman RM, Richards CJ. Studies on sulfate in end-stage renal disease. Kidney Int 15:167-75, 1979.

102.Freiberg JM, Kinsella J, Sacktor B. Glucocorticoids increase the Na-H exchange and decrease the $\mathrm{Na}$ gradient-dependent phosphate uptake systems in renal brush-border membrane vesicles. Proc Natl Acad Sci (USA) 79: 4932-4936, 1982.

103.Frick A, Durasin I, Neuweg M. Phosphaturic response of hydrocortisone in the presence and the absence of parathyroid hormone. Pflugers Arch 392:99-195, 1981.

104.Frick A, Durasin I. Regulation of the renal transport of inorganic sulfate: effects of metabolic changes in arterial blood pH. Pflugers Arch 407:541-546, 1986.

105.Friedlander G. Autocrine/paracrine control of renal phosphate transport. Kidney Int Suppl. 65: S18-S23, 1998.

106.Gattineni J, Bates C, Twombley K, Dwarakanath V, Robinson ML, Goetz R, Mohammadi M, Baum M. FGF23 decreases renal NaPi-2a and NaPi-2c expression and induces hypophosphatemia in vivo predominantly via FGF receptor 1. Am J Physiol 297: F282-F291, 2009. 
107.Gensure RC, Gardella TJ, Jüppner H. Parathyroid hormone and parathyroid hormone-related peptide, and their receptors. Biochem Biophys Res Commun 328: 666-678, 2005.

108.Giral H, Caldas $Y$, Sutherland E, Wilson P, Breusegem S, Barry N, Blaine J, Jiang T, Wang XX, Levi M. Regulation of rat intestinal Na-dependent phosphate transporters by dietary phosphate. Am J Physiol 297: F1466F1475, 2009.

109.Giral H, Lanzano L, Caldas Y, Blaine J, Verlander JW, Lei T, Gratton E, Levi M. Role of PDZ domain containing 1 (PDZK1) in apical membrane expression of renal Na-coupled phosphate (NaPi) transporters. J Biol Chem 2011.

110.Gisler SM, Kittanakom S, Fuster D, Wong V, Bertic M,Radanovic T, Hall RA, Murer H, Biber J, Markovich D, Moe OW, Stagljr I. Monitoring proteinprotein interactions between the mammalian renal epithelial integral membrane proteins and their PDZ interacting partners using the type II split ubiquitin membrane yeast two-hybrid system. Molec Cell Proteomics 7:13261377, 2008.

111.Glahn RP, Onsgard MJ, Tyce GM, Chinnow SL, Knox FG, Dousa TP. Autocrine/paracrine regulation of renal $\mathrm{Na}$-phosphate cotransport by dopamine. Am J Physiol 264: F618-F622, 1993.

112.Gloor HJ, Bonjour JP, Caverzasio J, Fleisch H. Resistance to the phosphaturic and calcemic actions of parathyroid hormone during phosphate depletion. J Clin Invest 63: 371-377, 1979.

113.Goudsmit A Jr, Power MH, Bollman JL. The excretion of sulfates by the dog. Am J Physiol 125: 506, 1939.

114.Greer FR, McCormick A, Loker J. Increased urinary excretion of inorganic sulfate in premature infants fed bovine milk protein. J Pediatr 109:692-697, 1986.

115.Greger RF, Lang FC, Knox G, Lechene CP. Absence of significant secretory flux of phosphate in the proximal convoluted tubule. Am J Physiol 232: F235-F238, 1977.

116.Grinstein S, Turner RJ, Silverman M, Rothstein A. Inorganic anion transport in kidney and intestinal brush border and basolateral membranes. Am J Physiol 238:F452- F460, 1980.

117.Gullans SR, Brazy PC, Mandel LJ, Dennis VW. Stimulation of phosphate transport in the proximal tubule by metabolic substrates. Am J Physiol 247: F582-F587, 1984. 
118.Guntupalli J, Eby B, Lau K. Mechanism for the phosphaturia of $\mathrm{NH}_{4} \mathrm{Cl}$ : dependence on acidemia but not on diet $\mathrm{PO}_{4}$ or PTH. Am J Physiol 242: F552-F560, 1982.

119. Hagenbuch B, Murer H. Phosphate transport across basolateral membrane from rat kidney cortex: sodium-dependence? Pflügers Arch 407: S149-S155, 1986.

120. Hagenbuch B, Stange G, Murer H. Transport of sulphate in rat jejunal and rat proximal tubular basolateral membrane vesicles. Pflügers Arch 405: $202-$ 208, 1985.

121. Hamadeh MJ, Hoffer LJ. Use of sulfate production as a measure of shortterm sulfur amino acid catabolism in humans. Am J Physiol Endocrinol Metab 280:E857-E866, 2001.

122. Hammerman MR, Karl IE, Hruska KA. Regulation of canine renal vesicle $\mathrm{Pi}$ transport by growth hormone and parathyroid hormone. Biochim Biophys Acta 603: 322-335, 1980.

123. Hammerman MR, Rogers S, Hansen VA, Gavin JR. Insulin stimulates Pi transport in brush border vesicles from proximal tubular segments. Am J Physiol 247: E616-E624, 1984.

124. Hammerman MR. The growth hormone-insulin-like growth factor axis in the kidney. Am J Physiol 257: F503-F514, 1989.

125. Haramati A, Haas JA, Knox FG. Adaptation of deep and superficial nephrons to changes in dietary phosphate intake. Am J Physiol 244: F265F269, 1983.

126. Harris CA, Sutton RAL, Dirka JH. Effects of hypercalcemia and tubular reabsorption in the rat. Am J Physiol 233: F201-F206, 1977.

127.Hästbacka J, de la Chapelle A, Mahtani MM, Clines G, Reeve-Daly MP, Daly M, Hamilton BA, Kusumi K, Trivedi B, Weaver A, Coloma A, Lovett M, Buckler A, Kaitila I, Lander ES. The diastrophic dysplasia gene encodes a novel sulfate transporter: positional cloning by fine-structure linkage disequilibrium mapping. Cell 78:1073-1087, 1994.

128. Herak-Kramberger CM, Spindler B, Biber J, Murer H, Sabolić I. Renal type II Na/Pi-cotransporter is strongly impaired whereas the $\mathrm{Na}$ /sulphatecotransporter and aquaporin 1 are unchanged in cadmium-treated rats. Pflugers Arch 432:336-344, 1996.

129. Hernando N, Gisler SM, Pribanic S, Deliot N, Capuano P, Wagner CA, Moe OW, Biber J, Murer H. NaPi-lla and interacting partners. Am J Physiol 567:21-26, 2005. 
130. Hierholzer K, Cade R, Gurd R, Kessler R, Pitts R. Stop flow analysis of renal reabsorption and excretion of sulfate in the dog. Am J Physiol 198: 833837,1960 .

131. Hoffer LJ. Methods for measuring sulfur amino acid metabolism. Curr Opin Clin Nutr Metab Care 5:511-517, 2002.

132.Honda S, Kashiwagi M, Ookata K, Tojo A, Hirose S. Regulation by 1.25dihydroxyvitamin D3 of expression of stanniocalcin messages in the rat kidney and ovary. FEBS Let 459: 119-122, 1999.

133. Houterman S, van Faassen A, Ocke MC, Habets LHM, van Dieijen-Visser MP, Bueno-de-Mesquita BH, Janknegt RA. Is urinary sulfate a biomarker for the intake of animal protein and meat? Cancer Lett 114: 295-296, 1997.

134.Hu MC, Shi M, Zhang J, Pastor J, Nakatani T, Lanske B, Shawkat Razzaque M, Rosenblatt KP, Baum MG, Kuro-O M, Moe OW. Klotho: a novel phosphaturic substance acting as an autocrine enzyme in the renal proximal tubule. FASEB J 24: 3438-3450, 2010.

135.Iharada M, Miyaji T, Fujimoto T, Hiasa M, Anzai N, Omote H, Moriyama Y. Type 1 sodium-dependent phosphate transporter (SLC17A1 Protein) is a Cl(-)-dependent urate exporter. J Biol Chem 285: 26107-26113, 2010.

136.Indridason OS, Quarles LD. Hyperphosphatemia in end-stage renal disease. Adv Ren Replace Ther 9: 184-192, 2002.

137.Isaac J, Berndt TJ, Chinnow SL, Tyce GM, Dousa TP, Knox FG. Dopamine enhances the phosphaturic response to parathyroid hormone in phosphate deprived rats. J Am Soc Nephrol 2: 1423-1429, 1992.

138.Ishibashi K, Imai M. Prospect of a stanniocalcin endocrine/paracrine system in mammals. Am J Physiol 282: F367-F375, 2002.

139.Ishibashi K, Matsuzaki T, Takata K, Imai M. Identification of a new member of type I Na/phosphate co-transporter in the rat kidney. Nephron Physiol 94: 10-18, 2003.

140.Issac J, Glahn RP, Appel MA, Onsgard M, Dousa TP, Knox FG. Mechanisms of dopamine inhibition of renal phosphate transport. J Am Soc Nephrol 2: 1601-1607, 1992.

141.Jaeger P, Bonjour JP, Karlmark B, Stanton B, Kirk RG, Duplinsky T, Giebisch $\mathrm{G}$. Influence of acute potassium loading on renal phosphate transport in the rat kidney. Am J Physiol 245: F601-605, 1983.

142.Jaeger P, Karlmark B, Bonjour JP, Giebisch G. Potassium imbalance and phosphate renal handling: a micropuncture study. Adv Exp Med Biol;151: 97102, 1982. 
143.Jiang Z, Asplin JR, Evan AP, Rajendran VM, Velazquez H, Nottoli TP, Binder $\mathrm{HJ}$, Aronson PS. Calcium oxalate urolithiasis in mice lacking anion transporter Slc26a6. Nat Genet 38: 474-478, 2006.

144.Jiang Z, Grichtchenko II, Boron WF, Aronson PS. Specificity of anion exchange mediated by mouse Slc26a6. J Biol Chem 277: 33963-33967, 2002.

145.Jutabha P, Anzai N, Kitamura K, Taniguchi A, Kaneko S, Yan K, Yamada $\mathrm{H}$, Shimada H, Kimura T, Katada T, Fukutomi T, Tomita K, Urano W, Yamanaka H, Seki G, Fujita T, Moriyama Y, Yamada A, Uchida S, Wempe MF, Endou H, Sakurai H. Human sodium-phosphate transporter 4 (hNPT4/SLC17A3) as a common renal secretory pathway for drugs and urate. J Biol Chem 285: 35123-35132, 2010.

146.Karniski LP, Lötscher M, Fucentese M, Hilfiker $\mathrm{H}$, Biber J, Murer $\mathrm{H}$. Immunolocalization of sat-1 sulfate/oxalate/bicarbonate anion exchanger in the rat kidney. Am J Physiol 275: F79-F87, 1998.

147.Karniski LP. Functional expression and cellular distribution of diastrophic dysplasia sulfate transporter (DTDST) gene mutations in HEK cells. Hum Mol Genet 13: 2165-2171, 2004.

148.Kavanaugh MP, Miller DG, Zhang W, Law W, Kozak SL, Kabat D, Miller AD. Cell-surface receptors for gibbon ape leukemia virus and amphotropic murine retrovirus are inducible sodium-dependent phosphate symporters. Proc Natl Acad Sci (USA) 91: 7071-7075, 1994.

149.Kempe DS, Dermaku-Sopjani M, Fröhlich H, Sopjani M, Umbach A, Puchchakayala G, Capasso A, Weiss F, Stübs M, Föller M, Lang F. Rapamycin-induced phosphaturia. Nephrol Dial Transplant 25: 2938-2944, 2010.

150.Kempson SA, Shah SV, Werness PG, Berndt T, Lee PH, Smith LH, Knox FG, Dousa TP. Renal brush border membrane adaptation to phosphorous deprivation: Effects of fasting versus low-phosphorous diet. Kidney Int 18: 36$47,1980$.

151.Keusch I, Traebert M, Lötscher M, Kaissling B, Murer H, Biber J. Parathyroid hormone and dietary phosphate provoke a lysosomal routing of the proximal tubular Na/Pi-cotransporter type II. Kidney Int 54:1224-1232, 1998.

152.Knauf F, Yang CL, Thomson RB, Mentone SA, Giebisch G, Aronson PS. Identification of a chloride-formate exchanger expressed on the brush border membrane of renal proximal tubule cells. Proc Natl Acad Sci (USA) 98:94259430, 2001. 
153. Knochel JP. Clinical and physiologic phosphate disturbances. In: The Kidney, Physiology and Pathphysiology, p1905-1934, 2000.

154.Kolek OI, Hines ER, Jones MD, LeSueur LK, Lipko MA, Kiela PR, Collins JF, Haussler MR, Ghishan FK. 1alpha,25-dihydroxyvitamin D3 upregulates FGF23 gene expression in bone: the final link in a renal-gastrointestinalskeletal axis that controls phosphate transport. Am J Physiol 289: G1036G1042, 2005.

155.Kone $\mathrm{BC}$, Balylis $\mathrm{C}$. Biosyntheisis and homeostatic roles of nitric oxide in the normal kidney. Am J Physiol 272: F561-F578, 1997.

156.Kreusser WJ, Kurokawa K, Aznar E, Massry SG. Phosphate depletion: effect on inorganic phosphorous and adenine nucelotides, urinary phosphate and calcium balance. Electrolyte Metab 1: 30-42, 1978.

157.Krick W, Schnedler N, Burckhardt G, Burckhardt BC. Ability of sat-1 to transport sulfate, bicarbonate, or oxalate under physiological conditions. Am J Physiol 297: F145-F154, 2009.

158. Krieger NS, Culbertson CD, Kyker-Snowman K, Bushinsky DA. Metabolic acidosis increases fribroblast growth factor 23 in neonatal mouse bone. Am J Physiol 303: F431-F436, 2012.

159.Krijgsheld KR, Scholtens E, Mulder GJ. Serum concentration of inorganic sulfate in mammals: species differences and circadian rhythm. Comp Biochem Physiol 67:683-86, 1980.

160.Kumar R. Tumor induced osteomalcia and the regulation of phosphate homeostasis. Bone 27: 333- 338, 2000.

161. Kumar R. Phosphate sensing. Curr Opin Nephrol Hypertens 18: 281-284, 2009.

162.Kuo SM, Aronson PS. Oxalate transport via the sulfate/HCO3 exchanger in rabbit renal basolateral membrane vesicles. J Biol Chem 263: 9710- 9717, 1988.

163.Kuo SM, Aronson PS. Pathways for oxalate transport in rabbit renal microvillus membrane vesicles. J Biol Chem 271:15491-15497, 1996.

164.Kuro-o M. A potential link between phosphate and aging-Lessons from Klotho-deficient mice. Mech Ageing Dev 131: 270-275, 2010.

165.Lapointe JY, Tessier J, Paquette Y, Wallendorff B, Coady MJ, Pichette V, Bonnardeaux A. NPT2a gene variation in calcium nephrolithiasis with renal phosphate leak. Kidney Int 69: 2261-2267, 2006. 
166.Larsson T, Marsell R, Schipani E, Ohlsson C, Ljunggren O, Tenenhouse HS, Jüppner $H$, Jonsson KB. Transgenic mice expressing fibroblast growth factor 23 under the control of the alpha1(I) collagen promoter exhibit growth retardation, osteomalacia, and disturbed phosphate homeostasis. Endocrinology 145:3087-3094, 2004.

167.Lederer ED, Sohi SS, McLeish KR. Dopamine regulates phosphate uptake by opossum kidney cells through multiple counter-regulatory receptors. J Am Soc Nephrol 9:975-985, 1998.

168.Lee A, Beck L, Markovich D. The human renal Na+ sulfate cotransporter (SLC13A1; hNaSi-1) cDNA and gene: organization, chromosomal localization and functional characterization. Genomics 70: 354-363, 2000.

169.Lee DBN, Walling MW, Brautbar N. Intestinal phosphate absorption: Influence of vitamin D and non-vitamin D factors. Am J Physiol 250: G369G373, 1986.

170.Lee HJ, Balasubramanian SV, Morris ME. Effect of pregnancy, postnatal growth, and gender on renal sulfate transport. Proc Soc Exp Biol Med 221:336-344, 1999.

171.Lee HJ, Balasubramanian SV, Murer H, Biber J, Morris ME. Modulation of sulfate renal transport by alterations in cell membrane fluidity. J Pharm Sci 88:976-980, 1999.

172.Lee HJ, Sagawa K, Shi W, Murer H, Morris ME. Hormonal regulation of sodium/sulfate co-transport in renal epithelial cells. Proc Soc Exp Biol Med 225:49-57, 2000.

173.Lee S, Dawson PA, Hewavitharana AK, Shaw PN, Markovich D. Disruption of NaS1 sulfate transport function in mice leads to enhanced acetaminophen-induced hepatotoxicity. Hepatology 43: 1241- 1247, 2006.

174.Lee S, Kesby JP, Muslim MD, Steane SE, Eyles DW, Dawson PA, Markovich D. Hyperserotonaemia and reduced brain serotonin levels in NaS1 sulphate transporter null mice. Neuroreport 18: 1981-1985, 2007.

175.LeGrimellec CL, Poujeol P, DeRouffignac C. ${ }^{3} \mathrm{H}$-inulin and electrolyte concentrations in Bowman's capsule in rat kidney. Pflügers Arch 354: 117131, 1975.

176.Lemann J, Bushinsky DA, Hamm LL. Bone buffering of acid and base in humans. Am J Physiol 285: F811-F832, 2003.

177.Levi M, Lötscher M, Sorribas V, Custer M, Arar M, Kaissling B, Murer H, Biber J. Cellular mechanisms of acute and chronic adaptation of rat renal $\mathrm{P}_{\mathrm{i}}$ transporter to alterations in dietary $\mathrm{P}_{(\mathrm{i})}$. Am J Physiol 267: F900-F908, 1994. 
178.Levi M, McDonald LA, Preisig PA, Alpern RJ. Chronic K depletion stimulates rat renal brush-border membrane Na-citrate cotransporter. Am J Physiol 261: F767-F773, 19

91.

179.Levi M, Shayman JA, Abe A, Gross SK, McCluer RH, Biber J, Murer H, Lötscher M, Cronin RE. Dexamethasone modulates rat renal brush border membrane phosphate transporter mRNA and protein abundance and glycosphingolipid composition. J Clin Invest 96:207-216, 1995.

180.Levi M. Heterogeneity of Pi transport by BBM from superficial and juxtameduallary cortex of rat. Am J Physiol 258: F1616-F1624, 1990.

181.Levine BS, Ho LD, Pasiecznik K, Coburn JW. Renal adaptation to phosphorous deprivation: characterization of early events. $J$ Bone Miner Res 1: 33-40, 1986.

182.Lin JH, Levy G. Renal clearance of inorganic sulfate in rats: effect of acetaminophen-induced depletion of endogenous sulfate. J Pharm Sci 72: 213-217, 1983.

183.Liu S, Gupta A, Quarles LD. Emerging role of fibroblast growth factor 23 in a bone-kidney axis regulating systemic phosphate homeostasis and extracellular matrix mineralization. Curr Opin Nephrol Hypertens 16: 329-335, 2007.

184.Loffing J, Lötscher M, Kaissling B, Biber J, Murer H, Seikaly M, Alpern RJ, Baum M, Moe OW. Renal Na/H exchanger NHE-3 and Na-PO4 cotransporter protein expression in glucocorticoid excess and deficient states. J Am Soc Nephrol 9: 1560-1567, 1998.

185.Lorenz-Depiereux B, Benet-Pages A, Eckstein G, Tenenbaum-Rakover Y, Wagenstaller J, Tiosamo D, Gershoni-Baruch R, Albers N, Lichtner P, Schnabel D, Hochberg Z, Strom TM. Hereditary hypophosphatemic rickets with hypercalcuria is caused by mutations in the sodium-phosphate cotransporter gene SLC34A3. Am J Hum Genet 78:193-201, 2006.

186.Lötscher M, Wilson P, Nguyen S, Kaissling B, Biber J, Murer H, Levi M. New aspects of adaptation of rat renal $\mathrm{Na}-\mathrm{Pi}$ cotransporter to alterations in dietary phosphate. Kidney Int 49, 1012-1018, 1996.

187.Lötscher M, Custer M, Quabius ES, Kaissling B, Murer H, Biber J. Immunolocalization of $\mathrm{Na} / \mathrm{SO} 4$-cotransport $(\mathrm{NaSi}-1)$ in rat kidney. Pflugers Arch 432: 373-378, 1996.

188.Low I, Friedrich T, Burckhardt G. Properties of an anion exchanger in rat renal basolateral membrane vesicles. Am J Physiol 246: F334-42, 1984. 
189.Lucke H, Stange G, Murer H. Sulphate/ion-sodium/ion cotransport by brush border membranes vesicles isolated from rat kidney cortex. Biochem $J$ 182: 223-229, 1979.

190.Magen D, Berger L, Coady MJ, Ilivitzki A, Militianu D, Tieder M, Selig S, Lapointe JY, Zelikovic I, Skorecki K. A loss of function mutation in NaPi-lla and renal Fanconi's syndrome. N Engl J Med 362: 1102 1109, 2010.

191. Mahon MJ. The parathyroid hormone receptorsome and the potential for therapeutic intervention. Curr Drug Targets 13: 116-128, 2012.

192.Marangella M, Petrarulo M, Cosseddu D, Vitale C, Linari F. Plasma profiles and removal rates of inorganic sulphate, and their influence on serum ionized calcium, in patients on maintenance haemodialysis. Clin Sci (Lond) 80:489-495, 1991.

193.Markovich D, Aronson PS. Specificity and regulation of renal sulfate transporters. Annu Rev Physiol 69:361-375, 2007.

194.Markovich D, Bissig M, Sorribas V, Hagenbuch B, Meier PJ, Murer H. Expression of rat renal sulfate transport systems in Xenopus laevis oocytes. Functional characterization and molecular identification. J Biol Chem 269: 3022-3026, 1994.

195.Markovich D, Fogelis TS. Ontogeny of renal sulfate transporters: postnatal mRNA and protein expression. Pediatr Nephrol 13:806-811, 1999.

196. Markovich D, Forgo J, Stange G, Biber J, Murer H. Expression cloning of rat renal $\mathrm{Na}^{+} / \mathrm{SO}_{4}{ }^{2-}$ cotransport. Proc Natl Acad Sci (USA) 90: 8073-8077, 1993.

197.Markovich D, James KM. Heavy metals mercury, cadmium, and chromium inhibit the activity of the mammalian liver and kidney sulfate transporter sat-1. Toxicol Appl Pharmacol 154:181-187, 1999.

198.Markovich D, Knight D. Renal Na-Si cotransporter NaSi-1 is inhibited by heavy metals. Am J Physiol 274:F283-F289, 1998.

199.Markovich D, Murer H, Biber J, Sakhaee K, Pak C, Levi M. Dietary sulfate regulates the expression of the renal brush border $\mathrm{Na} / \mathrm{Si}$ cotransporter $\mathrm{NaSi}-1$. J Am Soc Nephrol 9:1568-1573, 1998.

200.Bergeron MJ, Clemencon B, Hediger MA, Markovich D. SLC13 family of Na-coupled di- and tri-carboxylate/sulfate transporters. Mol Aspects Med 34: 299-312, 2013.

201.Markovich D, Wang H, Puttaparthi K, Zajicek H, Rogers T, Murer H, Biber J, Levi M. Chronic K depletion inhibits renal brush border membrane $\mathrm{Na}$ /sulfate cotransport. Kidney Int 55:244-251, 1999. 
202.Markovich D. Physiological roles and regulation of mammalian sulfate transporters. Physiol Rev 81:1499-1533, 2001.

203.Markovich D. Physiological roles of renal anion transporters NaS1 and Sat1. Am J Physiol Renal Physiol 300: F1267- F1270, 2011.

204. Markovich D. Slc13a1 and Slc26a1 KO models reveal physiological roles of anion transporters. Physiology 27: 7-14, 2012.

205.Markowitz M, Rotkin L, Rosen JF. Circadian rhythms of blood mineral in humans. Science 231: 672-674, 1981.

206.Marks J, Debnam ES, Unwin RJ. Phosphate homeostasis and the renalgastrointestinal axis. Am J Physiol 299: F285-F296, 2010.

207.Marks J, Srai SK, Biber J, Murer H, Unwin RJ, Debnam ES. Intestinal phosphate absorption and the effect of vitamin D: a comparison of rats with mice. Exp Physiol 91: 531-537, 2006.

208. Martin A, David V, Quarles LD. Regulation and function of the FGF23/Klotho endocrine pathways. Physiol Rev 92: 131-155, 2012.

209.Matsumoto N, Hemmi A, Yamato H, Ohnishi R, Segawa H, Ohno S, Miyamoto KI. Immunohistochemical analyses of parathyroid hormonedependent downregulation of renal type II Na-Pi cotransporters by cryobiopsy. J Med Invest 57: 138-145, 2010.

210.McKeown JW, Brazy PC, Dennis VW. Intrarenal heterogeneity for fluid, phosphate and glucose absorption in the rabbit. Am J Physiol 237: F312F318, 1979.

211.Mehls O, Krempien B, Ritz E, Schärer K, Schüler HW. Renal osteodystrophy in children on maintenance haemodialysis. Proc Eur Dial Transplant Assoc 10:197-201, 1973.

212.Michalk D, Klare B, Manz F, Schärer K. Plasma inorganic sulfate in children with chronic renal failure. Clin Nephrol 16:8-12, 1981.

213.Michalk D, Manz F, Muller-Wiefel DE, Scharer K. Renal handling of inorganic sulfate in children with chronic kidney disorders. Miner Electrolyte Metab 8:255-260, 1982.

214.Michalk D, Tschöpe W, Böhles HJ, Mehls O. Possible role of inorganic sulphate in the pathogenesis of hyperparathyroidism in chronic renal failure. Proc Eur Dial Transplant Assoc 18:561-566, 1981.

215.Miura In: Toxicology of Metals. Handbook of Experimental Pharmacology, edited by R.A. Goyer and M.G. Cherian New York, Springer-Verlag, 1986, Vol 80, p 179-194 
216.Miyamoto K, Haito-Sugino S, Kuwahara S, Ohi A, Nomura K, Ito M, Kuwahata M, Kido S, Tatsumi S, Kaneko I, Segawa H. Sodium-dependent phosphate cotransporters: lesions from gene knockout and mutation studies. J Pharm Sci 100: 3719-3730, 2011.

217.Mohebbi N, Kovacikova J, Nowik M, Wagner CA. Thyroid hormone deficiency alters expression of acid-base transporters in rat kidney. Am J Physiol 293:F416-427, 2007.

218.Morris ME, Benincosa LJ. Influence of NSAID-induced inhibition of renal prostaglandin synthesis on inorganic sulfate clearance in rats. Proc Soc Exp Biol Med 199:410-416, 1992.

219.Morris ME, Kwon O, Mansfield IL. Sulfate homeostasis. I. Effect of salicylic acid and its metabolites on inorganic sulfate in rats. J Pharmacol Exp Ther 244:945-949, 1988.

220.Morris ME, Levy G. Serum concentration and renal excretion by normal adults of inorganic sulfate after acetaminophen, ascorbic acid, or sodium sulfate. Clin Pharmacol Ther 33:529-536,1983.

221. Alper SL, Sharma AK. The SLC26 gene family of anion transporters and channels. Molec Aspects Med 34: 494 - 515, 2013.

222.Mulder GJ. 1981. Sulfate availability in vivo. In Sulfation of Drugs and Related Compounds, ed. GJ Mulder, pp. 32-52. Boca Raton, FL: CRC

223.Murer H, Ahearn G, Amstutz M, Biber J, Brown C, Gmaj P, Hagenbuch B, Malmström K, Mohrmann I, Mohrmann M, Stange G. Cotransport systems for inorganic sulfate and phosphate in small intestine and renal proximal tubule. Ann N Y Acad Sci 456:139-152, 1985.

224. Murer H, Hernando N, Forster I, Biber J. Proximal tubular phosphate reabsorption: Molecular mechanisms. Physiol Rev 80: 1373-1409, 2000.

225.Nagai S, Okazaki M, Segawa H, Bergwitz C, Dean T, Pott JJ, Mahon M, Gardella TJ, Jueppner H. Acute down-regulation of sodium-dependent phosphate transporter NPT2a involves preeominantly the cAMP/PKA pathway as revealed by signaling-selective parathyroid hormone analogs. $J$ Biol Chem 286: 1618-1626, 2011.

226.Neiberger RE. Adaptation of renal sulfate transport in response to dietary sulfate intake in guinea pigs. Child Nephrol Urol 11:61-64,1991.

227.Neiberger RE. Developmental changes in the renal capacity for sulfate reabsorption in the guinea pig. Pediatr Nephrol 6: 65-67, 1992.

228.Norbis F, Perego C, Markovich D, Stange G, Verri T, Murer H. cDNA cloning of a rat small-intestinal $\mathrm{Na}+/ \mathrm{SO} 4(2-)$ cotransporter. Pflugers Arch 428: 217-223, 1994. 
229.Nordin BEC. Calcium, phosphate and magnesium metabolism. New York: Churchill Livingstone, 1976, p. 22-26.

230.Nowik M, Picard N, Stange G, Capuano P, Tenenhouse HS, Biber J, Murer $\mathrm{H}$, Wagner $\mathrm{CA}$. Renal phosphaturia during metabolic acidosis revisted: molecular mechanisms for decreased renal phosphate rebasorption. Pflügers Arch-Eur J Physiol 457: 539-549, 2008.

231.Oerwad F, Azam N, Zhang M, Yamashita T, Tenenhouse H, Portale A. Dietary and serum phosphorous regulate fibroblast growth factor 23 expression and 1.25-dihydroxyvitamin D metabolism in mice. Endocrinology 146: 5358-5364, 2005.

232.Park SH, Taub M, Han HJ. Regulation of phosphate uptake in primary cultured rabbit renal proximal tubule cells by glucocorticoid: Evidence for nongenomic as well as genomic mechanisms. Endocrinology 142: 710-720, 2001.

233.Pelis RM, Edwards SL, Kunigelis SC, Claiborne JB, Renfro JL. Stimulation of renal sulfate secretion by metabolic acidosis requires $\mathrm{Na}+/ \mathrm{H}+$ exchange induction and carbonic anhydrase. Am J Physiol Renal Physiol 289:F208-F216, 2005.

234.Pena DR, Neiberger RE. Renal brush border sodium-sulfate cotransport in guinea pig: effect of age and diet. Pediatr Nephrol 11:724-727, 1997.

235.Perward F, Portale AA. Vitamin D metabolism in the kidney: regulation by phosphorous and fibroblast growth factor 23. Mol Cell Endocrinol 347: 17-24, 2011.

236.Picard N, Capuano P, Stange G, Mihailova M, Kaissling B, Murer H, Biber $\mathrm{J}$, Wagner $\mathrm{CA}$. Acute parathyroid hormone differentially regulates renal brush border membrane phosphate cotransporters. Pflugers Arch 460: 677-687, 2010.

237.Piscator In: Cadmium. Handbook of Experimental Pharmacology, edited by E.C. Foulkes, New York: Springer-Verlag, 1986, vol. 80, p 179-194

238.Portale AA, Halloran BP, Morris RC. Dietary intake of phosphorous modulates the circadian rhythm in serum concentration of phosphorous. $J$ Clin Invest 80: 1147- 1154, 1987.

239.Preisig PA, Alpern RJ. Chronic metabolic acidosis causes an adaptation in the apical membrane $\mathrm{Na} / \mathrm{H}$ antiporter and basolateral membrane $\mathrm{Na}(\mathrm{HCO} 3) 3$ symporter in the rat proximal convoluted tubule. J Clin Invest 82:1445-1453, 1988. 
240. Prie D, Friedlander $G$. Genetic disorders of renal phosphate transport. $N$ Engl J Med 362: 2399-2409, 2010.

241.Pritchard JB, Renfro JL. Renal sulfate transport at the basolateral membrane is mediated by anion exchange. Proc Natl Acad Sci (USA) 80:2603-7, 1983.

242.Pritchard JB. Sulfate-bicarbonate exchange in brush-border membranes from rat renal cortex. Am J Physiol 252:F346-F56, 1987.

243.Puttaparthi K, Markovich D, Halaihel N, Wilson P, Zajicek HK, Wang H, Biber J, Murer H, Rogers T, Levi M. Metabolic acidosis regulates rat renal NaSi cotransport activity. Am J Physiol 276:C1398-C1404, 1999.

244.Radanovic T, Wagner CA, Murer H, Biber J. Regulation of intestinal phosphate transport: I. Segmental expression and adaptation to phosphate deprivation of type Ilb Na/ $\mathrm{P}_{\mathrm{i}}$-cotransporter in mouse small intestine. $\mathrm{Am} \mathrm{J}$ Physiol 288: 496-500, 2005.

245.Ravera S, Virkki LV, Murer H, Forster IC. Deciphering PiT transport kinetics and substrate specifity using electrophysiology and flux measurements. Am J Physiol 293: C606-C620, 2007.

246. Reimer RJ. SLC17: A functionally diverse family of organic anion transporters. Molec Aspects of Med 34: 350 -359, 2013.

247.Renfro JL, Clark NB, Metts RE, Lynch MA. Glucocorticoid inhibition of NaSO4 transport by chick renal brush-border membranes. Am J Physiol 256:R1176-R1183, 1989.

248.Renfro JL. Adaptability of marine teleost renal inorganic sulfate excretion: evidence for glucocorticoid involvement. Am J Physiol 257:R511-R516, 1989.

249. Ritthaler T, Traebert M, Lötscher M, Biber J, Murer H, Kaissling B. Effects of phosphate intake on distribution of type $1 / \mathrm{Na}^{+} / \mathrm{P}_{\mathrm{i}}$-cotransporter mRNA in rat kidney. Kidney Int 55: 976-983,1999.

250.Rouse D, Suki WN. Modulation of phosphate ansorption by calcium in the rabbit proximal convoluted tubule. J Clin Invest 76: 630-636, 1985.

251.Sabbagh Y, O'Brien SP, Song W, Boulanger JH, Stockmann A, Arbeeny $\mathrm{C}$, Schiavi SC. Intestinal npt2b plays a major role in phosphate absorption and homeostasis. J Am Soc Nephrol 20: 2348-2358, 2009.

252.Sabry ZI, Shadarevian SB, Cowan JW, Campbell JA. Relationship of dietary intake of sulphur amino-acids to urinary excretion of inorganic sulphate in man. Nature 206: 931-933, 1965. 
253.Sagawa K, Benincosa LJ, Murer H, Morris ME. Ibuprofen-induced changes in sulfate renal transport. J Pharmacol Exp Ther 287:1092-1097, 1998.

254.Sagawa K, Darling IM, Murer H, Morris ME. Glucocorticoid-induced alterations of renal sulfate transport. J Pharmacol Exp Ther 294:658-663, 2000.

255.Sagawa K, DuBois DC, Almon RR, Murer H, Morris ME. Cellular mechanisms of renal adaptation of sodium dependent sulfate cotransport to altered dietary sulfate in rats. J Pharmacol Exp Ther 287:1056-1062, 1998.

256.Sagawa K, Han B, DuBois DC, Murer H, Almon RR, Morris ME. Age- and growth hormone-induced alterations in renal sulfate transport. $J$ Pharmacol Exp Ther 290:1182-1187, 1999.

257.Sagawa K, Murer $\mathrm{H}$, Morris ME. Effect of experimentally induced hypothyroidism on sulfate renal transport in rats. Am J Physiol 276:F164F171, 1999.

258. Saito H, Kusano K, Kinosaki M, Ito H, Hirata M, Segawa H, Miyamoto K, Fukushima N. Human fibroblast growth factor-23 mutants suppress $\mathrm{Na}^{+}-$ dependent phosphate cotransport activity and 1alpha,25-dihydroxyvitamin D3 production. J Biol Chem 278: 2206-2211, 2003.

259.Schmitt R, Klussmann E, Kahl T, Ellison DH, Bachmann S. Renal expression of sodium transporters and aquaporin-2 in hypothyroid rats. Am J Physiol 284: F1097-F1104, 2003.

260.Schneider EG, Durham JC, Sacktor B. Sodium-dependent transport of inorganic sulfate by rabbit renal brush-border membrane vesicles. J Biol Chem 259:14591-14599, 1984.

261.Schwab SJ, Klahr S, Hammerman MR. Na+-gradient-dependent Pi uptake in basolateral membrane vesicles from dog kidney. Am J Physiol 246: F663-F669, 1984.

262.Schwab SJ, Klahr S, Hammerman MR. Uptake of Pi in basolateral vesicles after release of unilateral ureteral obstruction. Am J Physiol 247: F543-F547, 1984.

263.Sebastian A, Hernandez RE, Portale AA, Colman J, Tatsuno J, Morris $\mathrm{RC}$. Dietary potassium influences kidney maintenance of serum phosphorus concentration. Kidney Int 37:1341-9, 1990.

264.Segawa H, Onitsuka A, Kuwahata M, Hanabusa E, Furutani J, Kaneko I, Tomoe Y, Aranami F, Matsumoto N, Ito M, Matatsumoto M, Li M, Amizuka N, Miyamoto K. Type llc sodium-dependent phosphate transporters regulates calcium metabolism. J Am Soc Nephrol 20: 104-113, 2009. 
265.Segawa $H$, Yamanaka $S$, Ito $M$, Kuwahata $M$, Shono $M$, Yamamoto $T$, Miyamoto K. Internalization of renal type llc Na-Pi cotransporter in response to a high-phosphate diet. Am J Physiol 288: F587-F596, 2004.

266.Segawa H, Yamanaka S, Onitsuka A, Tomoe Y, Kuwahata M, Ito M, Taketani Y, Miyamoto K. Parathyroid hormone-dependent endocytosis of renal type llc cotransporter. J Am Physiol 292: F395-F403, 2007.

267.Sestoft $\mathrm{L}$. Is the relationship between the plasma concentration of inorganic phosphate and the rate of oxygen consumption of significance in regulating energy metabolism in mammals?. J Clin Invest 39: 191-197, 1979.

268.Shenolikar S, Voltz JW, Minkoff CM, Wade J, Weinman EJ. Targeted disruption of the mouse gene encoding a PDZ domain containing protein adaptor, NHERF-1, promotes Npt2 internalization and renal phosphate wasting. Proc Natl Acad Sci (USA) 99:11470-11475, 2002.

269.Shimada T, Kakitani M, Yamazaki Y, Hasegawa H, Takeuchi Y, Fujita T, Fukumoto S, Tomizuka K, Yamashita T. Targeted ablation of Fgf23 demostrates an essential physiological role of FGF23 in phosphate and vitamin D metabolism. J Clin Invest 113: 561-568, 2004.

270.Shimada T, Mizutani S, Muto T, Yoneya T, Hino R, Takeda S, Takeuchi Y, Fujita T, Fukumoto S, Yamashita T. Cloning and characterization of FGF23 as a causative factor of tumor-induced osteomalacia. Proc Natl Acad Sci (USA) 98:6500-6005, 2001.

271.Silve C, Friedlander G. Renal regulation of phosphate excretion. In: Seldin GW, Giebisch G, eds. The kidney: Physiology and Pathophysiology. New York: Lippincott Williams \& WWilkins; pp 1885-1904, 2000.

272.Silver J, Naveh-Many T. FGF23 and the parathyroid. Adv Exp Med Biol 728: 92-99, 2012.

273.Soleimani M, Bergman JA, Hosford MA, McKinney TD. Potassium depletion increases luminal $\mathrm{Na}^{+} / \mathrm{H}^{+}$exchange and basolateral $\mathrm{Na}^{+}: \mathrm{CO}^{=}: \mathrm{HCO}^{-}$cotransport in rat renal cortex. J Clin Invest 86:1076-1083, 1990.

274.Specktor PC, Indelman M, Specher E. Hyperphosphatemic familial tumoral calcinosis caused by a mutation in GALNT3 in a European kindred. $J$ Hum Genet 51: 487-490, 2006.

275.Stephenson RK, Sole MJ, Baines AD. Neural and extraneural catcholamine production by rat kidneys. Am J Physiol 242: F261-F266, 1982. 
276.Stock JL, Coderre JA, Posillico JT. Effects of estrogen on mineral metabolism in postmenopausal women as evaluated by multiple assays measuring parathyrin bioactivity. Clin Chem 35:18-22, 1989.

277.Stoll R, Kinne R, Murer H. Effect of dietary phosphate intake on phosphate transport by isolated rat renal brush-border vesicles. Biochem $\mathrm{J}$ 180:465-470, 1979.

278.Strickler JC, Thompson DD, Klose RM, Giebisch G. Micropunture study of inorganic phosphate excretion in the rat. J Clin Invest 43: 1596-1607, 1964.

279. Strom TM, Jüppner H. PHEX, FGF23, DMP1 and beyond. Curr Opin Nephrol Hypertens 17: 357-362, 2008.

280.Suzuki M, Kawaguchi Y, Momose M, Morita T, Yokoyama K, Miyahara T. 1,25-Dihydroxyvitamin D stimulates sodium-dependent phosphate transport by renal outer cortical brush-border membrane vesicles by directly affecting membrane fluidity. Biochem Biophys Res Commun 150:1193-1198, 1988.

281. Takei Y, Yamamoto H, Masuda M, Sato T, Taketani Y, Takeda E. Stanniocalcin 2 is positively and negatively controlled by 1,25(OH)2D3 and PTH in renal proximal cells. J Mol Endocrinology 42: 261-268, 2009.

282.Taketani Y, Segawa H, Chikamori M, Morita K, Tanaka K, Kido S, Yamamoto H, lemori Y, Tatsumi S, Tsugawa N, Okano T, Kobayashi T, Miyamoto KI, Takeda E. Regulation of type II renal Na-dependent inorganic phosphate transporters by 1,25-dihydroxyvitamin D3. J Biol Chem 273: 14575-14581, 1998.

283.Tallgren LG. Inorganic sulphates in relation to the serum thyroxine level and in renal failure. Acta Med Scand (Suppl) 640:1-100, 1980.

284.Talor Z, Gold RM, Yang WC, Arruda JAL. Anion exchanger is present in both luminal and basolateral renal membranes. Eur J Biochem 164: 695-702, 1987.

285.Tenenhouse HS, Klugerman AH, Gurd W, Lapointe M, Tannenbaum GS. Pituitary involvement in renal adaptation to phosphate deprivation. $\mathrm{Am} \mathrm{J}$ Physiol 255: R373-R378, 1988.

286. Tenenhouse HS, Lee J, Harvey N. Renal brush-border membrane $\mathrm{Na}(+)-$ sulfate cotransport: stimulation by thyroid hormone. Am J Physiol 261:F420F426, 1991.

287.Tenenhouse HS. X-linked hypophosphatemia: a homologous disorder in humans and mice. Nephrol Dial Transplant 14: 333-341, 1999. 
288. Tenenhouse HS. Regulation of phosphorus homeostasis by the type lla $\mathrm{Na}$ /phosphate cotransporter. Annu Rev Nutr 25: 197-214, 2005.

289. Throler U, Bonjour JP, Fleisch H. Inorganic phosphate homeostasis: renal adaptation to the dietary intake in intact and thyroparathyroidectomized rats. $J$ Clin Invest 57: 264-273, 1976.

290.Thumfart J, Jung S, Amasheh S, Krämer S, Peters H, Sommer K, Biber J, Murer H, Meij I, Querfeld U, Wagner CA, Müller D. Magensium stimulates renal phosphate reabsorption. Am J Physiol 295: F1126-F1133, 2008.

291.Tomoe Y, Segawa H, Shiozawa K, Kaneko I, Tominaga R, Hanabusa E, Aranami F, Furutani J, Kuwahara S, Tatsumi S, Matsumoto M, Ito M, Miyamoto K. Phosphaturic action of fibroblast growth factor 23 in Npt2 null mice. Am J Physiol 298: F1314- F1350, 2010.

292.Tonelli M, Curhan G, Pfeffer M, Sacks F, Thadhani R, Melamed ML, Wiebe N, Muntner P. Relation between alkaline phosphatase, serum phosphate, and all-cause or cardiovascular mortality. Circulation 120: 17841792, 2009.

293.Traebert M, Völkl H, Biber J, Murer H, Kaissling B. Luminal and contraluminal action of 1-34 and 3-34 PTH peptides on renal type lla Na-Pi cotransporter. Am J Physiol 278: F792-F798, 2000.

294.Turner RJ. Sodium-dependent sulfate transport in renal outer cortical brush border membrane vesicles. Am J Physiol 247: F793-F798, 1984.

295. Uemura H, Irahara M, Yoneda N, Yasui T, Genjida K, Miyamoto K, Aono $\mathrm{T}$, Takeda E. Close correlation between estrogen treatment and renal phosphate reabsorption capacity. J Clin Endocrinology \& Metabolism 85: 1215-1219, 2000.

296. Ullrich KJ, Murer H. Sulphate and phosphate transport in the renal proximal tubule. Phil Trans R Soc Lond 299: 549-558, 1982.

297. Ullrich KJ, Rumrich G, Kloess S. Bidirectional active transport of thiosulfate in the proximal convolution of the rat kidney. Pflügers Arch 387: 127-132, 1980.

298. Ullrich KJ, Rumrich G, Kloess S. Contraluminal sulfate transport in the proximal tubule of the rat kidney. I. Kinetics, effects of $\mathrm{K}+, \mathrm{Na}+, \mathrm{Ca}+, \mathrm{H}+$ and anions. Pflugers Arch 402:264-71, 1984.

299.Ullrich KJ, Rumrich G, Kloess S. Contraluminal sulfate transport in the proximal tubule of the rat kidney. II. Specificity: sulfate-ester, sulfonates and amino sulfonates. Pflugers Arch 404:293-299, 1985. 
300.Ullrich KJ, Rumrich G, Kloess S. Contraluminal sulfate transport in the proximal tubule of the rat kidney. III. Specificity: disulfonates, di- and tricarboxylates and sulfocarboxylates. Pflugers Arch 404:300-306, 1985.

301.Ullrich KJ, Rumrich G, Kloess S. Contraluminal sulfate transport in the proximal tubule of the rat kidney. IV. Specificity: Salicylate analogs. Pflügers Arch 404: 307-310, 1985.

302.Ullrich KJ, Rumrich G, Kloess S. Contraluminal sulfate transport in the proximal tubule of the rat kidney. V. Specificity: phenophthaleins, sulfonphthaleins and other sulfodyes, sulfamoyl compounds and dyphenylamine-2-carboxylates. Pflügers Arch. 404: 311-318, 1985.

303.Ullrich KJ, Rumrich G, Kloss S. Phosphate transport in the proximal convolution of the rat kidney. I. Tubular heterogeneity, effect of parathyroid hormone in acute and chronic parathyroidectomized animals and effect of phosphate diet. Pflügers Arch 372: 269-274, 1977.

304.Ullrich KJ, Rumrich G, Kloss S. Phosphate transport in the proximal convolution of the rat kidney. II. Effect of extracellular $\mathrm{Ca}^{2+}$ and application of the $\mathrm{Ca}^{2+}$ ionophore A23187 in chronic PTX animals. Pflugers Arch 375: 97103, 1978.

305.Ullrich KJ, Rumrich G. Contraluminal transport systems in the proximal renal tubule involved in secretion of organic anions. Am J Physiol Renal Fluid Electrolyte Physiol 254: F453-F462, 1988.

306.Urokawa I, Yamazaki Y, Shimada T, lijima K, Hasegawa H, Okawa K, Fujita T, Fukumoto S, Yamashita T. Klotho converts canonical FGF receptor into a specific receptor for FGF23. Nature 444:770-774, 2007.

307.Vacca CV, Hines JD, Hall PW 3rd. The proteinuria of industrial lead intoxication. Environ Res 41:440-446, 1986.

308. Villa-Bellosta R, Barac-Nieto M, Breusegem SY, Barry NP, Levi M, Sorribas V. Interactions of the growth-related, type Ilc renal sodium/phosphate cotransporter with PDZ proteins. Kidney Int 73: 456-464, 2008

309. Villa-Bellosta R, Ravera S, Sorribas V, Stange G, Levi M, Murer H, Biber J, Forster IC. The Na-Pi cotransporter PiT-2 (SLC20A2) is expressed in the apical membrane of rat proximal tubules and regulated by dietary $\mathrm{Pi}$. $A m \mathrm{~J}$ Physiol 296: F691-F699, 2008

310.Villa-Bellosta R, Sorribas V. Compensatory regulation of the sodium/phosphate cotransporters NaPi-Ilc (SCL34A3) and Pit-2 (SLC20A2) during Pi deprivation and acidosis. Pflugers Arch-Europ J Physiol 459: 499-508, 2010. 
311.Vincourt JB, Jullien D, Amalric F, Girard JP. Molecular and functional characterization of SLC26A11, a sodium-independent sulfate transporter from high endothelial venules. FASEB J. 17: 890-892, 2003.

312.Virkki LV, Forster IC, Biber J, Murer H. Substrate interactions in the human type lla sodium-phosphate cotransporter (NaPi-lla). Am J Physiol 288: F969-F981, 2005.

313.Vrtovsnik F, Jourdain M, Cherqui G, Lefebvre J, Friedlander G. Glucocorticoid inhibition of $\mathrm{Na}$-Pi cotransport in renal epithelial cells is mediated by protein kinase C. J Biol Chem 269:8872-8877, 1994.

314.Wagner GF, Dimattia GE. The stanniocalcin family of proteins. J Exp Zool A Comp Exp Biol 305:769-780, 2006.

315. Wagner CA, Hernando N, Forster IC, Biber J. The SLC34 family of sodium-dependent phosphate transporters. Pflügers Arch 2013 (in press) 316.Wagner GF, Vozzolo BL, Jaworski E, Haddad M, Kline RL, Olsen HS, Rosen CA, Davidson MB, Renfro JL. Human stanniocalcin inhibits renal phosphate excretion in the rat. J Bone Miner Res 12: 165-171, 1997.

317.Walton RJ, Biijvoet OLM. Nomogram for the derivation of renal threshold phosphate concentration. Lancet ii: 309-310, 1975.

318.Webster SK, Haramati A, Knox FG. Effect of dexamethasone on segmental phosphate reabsorption in phosphate-deprived rats. Am J Physiol 251: F576-F580, 1986.

319.Wedel BJ, Gabers DL. New insights on the functions of the guanylyl cyclase receptors. FEBS Lett 410: 29-33, 1997.

320.Weinman EJ, Biswas R, Steplock D, Douglas TS, Cunningham R, Shenolikar S. Sodium-hydrogen exchanger regulatory factor-1 (NHERF-1) transduces signals that mediate dopamine inhibition of sodium-phosphate cotransport in mouse kidney. J Biol Chem 285: 13454-13460, 2010.

321. Weinman EJ, Biswas R, Steplock D, Wang P, Lau YS, Desir GV, Shenolikar S. Increased renal dopamine and acute renal adapatation to a high-phosphate diet. Am J Physiol 300: F1123-F1129, 2011.

322.Weinman EJ, Biswas RS, Peng G, Shen L, Turner CL, E X, Steplock D, Shenolikar S, Cunningham R. Parathyroid hormone inhibits renal phosphate transport by phosphorylation of serine 77 of sodium-hydrogen exchanger regulatory factor-1. J Clin Invest 117:3412-3420, 2007.

323.Weinman EJ, Steplock D, Cha B, Kovbasnjuk O, Frost NA, Cunningham $\mathrm{R}$, Shenolikar S, Blanpied TA, Donowitz M. PTH transiently increases the percent mobile fraction of Npt2a in OK cells as determined by FRAP. Am J Physiol 297:F1560-1565, 2009. 
324.Werner A, Moore ML, Mantei N, Biber J, Semenza G, Murer H.Cloning and expression of cDNA for a $\mathrm{Na} / \mathrm{Pi}$ cotransport system of kidney cortex.

Proc Natl Acad Sci (USA) 88: 9608-9612, 1991.

325.White KR, Larsson TE, Econs M. The roles of specific genes implicated as circulating factors involved in normal and disordered phosphate homeostasis: frizzled related protein-4, matrix extracellular phosphoglycoprotein, and firbroblast growth factor 23. Endocr Rev 27: 221$241,2006$.

326.Woda CB, Halaihel N, Wilson PV, Haramati A, Levi M, Mulroney SE. Regulation of renal $\mathrm{NaPi}-2 \mathrm{a}$ expression and tubular phosphate reabsorption by growth hormone in the juevenile rat. Am J Physiol 287: F117-F123, 2004.

327. Yamashita T, Konishi M, Miyake A, Inui K, Itoh N. Fibroblast growth factor (FGF)-23 inhibits renal phosphate reabsorption by activation of the mitogenactivated protein kinase pathway. J Biol Chem 277: 28265-28270, 2002.

328. Yusufi AK, Murayama N, Keller MJ, Dousa TP. Modulatory effect of thyroid hormones on uptake of phosphate and other solutes across luminal brush border membrane of kidney cortex. Endocrinology 116: 2438-2449, 1985.

329.Yusufi AN, Berndt TJ, Murayama N, Knox FG, Dousa TP. Calcitonin inhibits $\mathrm{Na}$ gradient dependent phosphate uptake across renal brush-border membrane. Am J Physiol 252: F598-F604, 1987.

330.Yusufi ANK, Berndt TJ, Moltaji H, Donovan V, Dousa TP, Knox FG. Rat atrial natriuretic factor (ANP-III) inhibits phosphate transport in brush border membrane from superficial and juxtamedullary cortex. Proc Soc Exp Biol Med 190: 87-90, 1989.

331.Zajicek HK, Wang H, Puttaparthi K, Halaihel N, Markovich D, Shayman J, Beliveau R, Wilson P, Rogers T, Levi M. Glycosphingolipids modulate renal phosphate transport in potassium deficiency. Kidney Int 60: 694-704, 2001.

332.Zhang MY, Wang X, Wang JT, Compagnone NA, Mellon SH, Olson JL, Tenenhouse HS, Miller WL, Portale AA. Dietary phosphorous transcriptionally regulates 25-hydroxyvitamin D-1alpha-hydroxylase gene expression in the proximal renal tubule. Endorcrinology 143: 587-595, 2002. 